\title{
Transição e/ou modernização do Leste Europeu
}

\section{LÁSZLÓ CSABA}

A PRIMEIRA PERGUNTA a ser feita sobre os países que compõe a Europa Oriental é: o que os torna diferentes de outros países subdesenvolvidos na periferia do sistema econômico mundial? A resposta mais simples é, naturalmente, seu poder militar e sua localização geográfica. A Rússia ainda mantém o maior exército na Europa continental, com um contingente de mais de 2,5 milhões. Até dezembro de 1994, além da Rússia, a Ucrânia e o Cazaquistão seguiam sua própria política nuclear e somente a Belorus declarou seu desinteresse em reter o arsenal nuclear. Em segundo lugar, a geografia não segue os novos desenvolvimentos no comércio, tecnologia ou tendências intelectuais, tendo reposicionado seu foco no eixo transatlântico. Portanto, os desastres de várias espécies - desde as repercussões da usina nuclear de Chernobil, ainda em funcionamento, até os intermináveis conflitos inter-étnicos na Bósnia, produzindo centenas de milhares de refugiados - estão fadados a se espalhar mais rapidamente em países centrais da União Européia do que os cataclismas que possam ocorrer em outros lugares. Em terceiro lugar, a maioria desses países, em termos históricos, culturais, religiosos e mesmo políticos e militares, têm sido parte integrante do cenário pan-europeu, especialmente nos últimos dois séculos. Em esportes, política, artes, ciências, música, questões individuais e, mesmo, contatos familiares, várias nações da Europa Central e Oriental não apenas se sentem, mas se tornaram de fato partes integrantes do velho continente no período pré-Yalta.

Os antecedentes econômicos desses países têm sido substancial e igualmente divergentes antes e depois da Guerra Fria (1), variando desde as Terras Tchecas, com renda per capita excedendo os níveis austríacos em 1920, até a Albânia, que tradicionalmente tem sido a sociedade islâmica mais atrasada da Europa. O que eles têm em comum é o destino que compartilhavam até recentemente, a saber, a maioria deles fazia parte do império soviético e todos estavam sujeitos à economia de comando, de uma forma ou outra. Em outras palavras, cada um deles tornou-se subjugado ao maior experimento de engenharia social da história moderna: a tentativa de modernização do socialismo de Estado.

É importante manter em mente os dois componentes que moldaram as especificidades desse grupo de países: a busca imperial russo/soviética e a ideologia socialista, que inspiraram várias escolhas individuais, já que negligenciar qualquer uma delas apresenta uma visão tendenciosa de desenvolvimento. Ao mesmo tempo, é igualmente importante ressaltar, tais países passaram por uma grandiosa tentativa de modernização, iniciada e imposta de cima para baixo. Essa 
tentativa, ainda que de maneira extremada, tinha como meta alcançar a modernidade segundo o definido por Max Weber (1972): congruência qualitativa com as mais avançadas sociedades capitalistas (de fato, com a inclusão de vários aspectos do estado de bem-estar).

Contudo, conforme evidenciam as análises científicas e a experiência cotidiana, o experimento fracassou. Nem na competitividade internacional, nem na inovação, sem falar de outros aspectos qualitativos da vida, como garantia de liberdades individuais, maior atenção aos bens públicos ou preservação do equilíbrio ecológico, nos quais os sistemas centralizados parecem desfrutar de vantagens incontestáveis sobre os mercados privados, as sociedades européias centrais e orientais conseguiram superar o desempenho de seus pares ocidentais. Mesmo em termos de indicadores quantitativos (2), o desempenho dos ex-países socialistas foi pior. Corrigidos os erros intencionais de relatórios e as distorções conceituais, constata-se que a fase de tentar alcançar os países mais desenvolvidos chegou ao fim por volta do final da década de 60. Desde então, embora o esforço de investimento dos países socialistas excedessem àquele dos países da OCDE, - Organização para a Cooperação e Desenvolvimento Econômico - em 5-7 pontos percentuais em média, o crescimento incremental ainda foi inferior ao do Ocidente. Como o Ocidente, especialmente a Europa Ocidental, entrou em longa fase de crescimento relativamente modesto nas duas últimas décadas, $\mathrm{o}$ potencial dos países atrasados para alcançá-la deve ter sido considerável, conforme evidenciado pelos novos países em industrialização (NICs). Entretanto, esse potencial não foi utilizado sob o socialismo. Por isso, a combinação de maior esforço de investimento com menores resultados levou a uma desvantagem cumulativa nos padrões de vida dos países que começaram a corrida partindo de um nível relativamente menor de desenvolvimento desde o seu início. Sua abertura, isto é, constantes comparações com o Ocidente torna esse aspecto manifesto.

É importante observar que o socialismo tamponco produziu uma sociedade mais eqüitativa. Em primeiro lugar, a renda, a carreira e as perspectivas, estavam vinculadas mais às hierarquias que ao desempenho, o que lembrava muito o feudalismo. Em segundo, os diferenciais de renda média de 1:5 a 1:7, ou seja, proporções típicas da Europa Ocidental, prevaleceram durante todo o período socialista na maioria dos países (com a possível exceção da Albânia e da Coréia do Norte). Em terceiro, o regime não produziu melhor provisão de bens e serviços públicos que o capitalismo contemporâneo. Em quarto lugar, não produziu uma moderna sociedade pós-industrial, mas conservou estruturas industriais antiquadas do período da Primeira Guerra Mundial. Em resumo, o freqüentemente lembrado trade off "igualdade versus eficiência" (Okun, 1975) não parece ter desempenhado um papel significativo nas decisões públicas, como na resistência às reformas na década de 70 ou no apoio à mudança sistêmica em 1989/91.

$\mathrm{Na}$ realidade, foi o destino do poder militar russo e o correlato poder político que se mostrou decisivo na determinação do ciclo real de vida deste 
experimento particular. A introdução paralela do planejamento central e do domínio do partido único em 1948 ocorreu simultaneamente em toda a região, da mesma forma que o colapso do sistema em 1989/90, seguido - com um ano de atraso - pela própria Rússia. Mesmo na Iugoslávia, o acordo russo-americano de dezembro de 1989 sobre a retirada das tropas da Europa Central e Oriental desencadeou a condução do conflito inter-étnico latente a um conflito militar aberto. Em resumo, além das diversas características do subdesenvolvimento, como a dívida, a fraca governança, o populismo macroeconômico ou a ausência de competitividade, o grupo de países da Europa Central e Oriental de fato apresenta-se com algumas peculiaridades claramente discerníveis. Isso torna-se manifesto no tipo de problemas que uma estratégia de desenvolvimento bemsucedida precisa abordar. Além da estabilização convencional e dos problemas de ajustamento, há tarefas específicas relacionadas às distorções provocadas pelo sistema socialista e pelo império soviético que precisam ser corrigidos. A coexistência de países periféricos dependentes com um país central colonialista menos do que mais desenvolvido (3) é fenômeno um tanto excepcional na história econômica; o horizonte multidimensional de longo prazo e a natureza peculiar da transformação da Europa Central e Oriental tornam-se bem delineados.

\section{Visão geral de um dos impasses da modernização}

É importante ter em mente que - ao contrário das profecias de Marx - as revoluções socialistas em todo o mundo só conseguiram triunfar em países atrasados. Sua vitória muitas vezes confundiu-se com um forte movimento nacional, seja na forma de descolonização, como na China, no Vietnã e em Cuba, ou no contexto de guerras mundiais, como na Rússia em 1917 ou na Sérvia em 1945. Portanto, foi inevitável que a redução do hiato de desenvolvimento com relação aos países mais desenvolvidos fosse altamente relevante para a legitimação do sistema e a determinação das prioridades da industrialização socialista. Além disso, segundo o princípio da ação-e-reação, os regimes revolucionários sem dúvida estavam certos em esperar fortes reações adversas interna e externamente, já que em nenhum lugar e nunca conseguiriam conquistar a legitimação democrática por intermédio de eleições livres. Por isso, foi escolhido um tipo peculiar de estratégia de desenvolvimento para reduzir o hiato: industrialização forçada com ênfase bem-definida na indústria pesada, mais particularmente nas indústrias da defesa e ligadas a ela.

Essa opção foi feita inicialmente pela Rússia em 1926-28, com outros países seguindo o seu exemplo automaticamente, desde Coréia do Norte até Cuba, sem muita hesitação ou especulação sobre seus distintos caminhos nacionais. No debate sobre a industrialização russa (4), a questão foi anunciada de forma abrupta. Se a opção tivesse sido por um desenvolvimento orgânico, tal escolha teria implicado em:

- coexistência de longo prazo com os pequenos produtores de mercadorias, o predominante campesinato e a classe de comerciantes; 
- não-possibilidade de um rápido desenvolvimento militar, a qualquer custo;

- não-tolerância de uma versão radical de engenharia social, na qual os idealizadores do sistema insistiram não somente em sua visão específica a ser implementada, mas também no ritmo com que atingir suas metas. Da mesma forma, qualquer retroalimentação corretiva ou dúvida sobre tais pontos era considerada indesejável e decididamente prejudicial.

O estado totalitário é o único meio (5) de se atingir de fato essas metas, contra as preferências mais ou menos explícitas da maioria, mas em nome da vanguarda, que esperava propiciar a modernização acelerada como subproduto e legitimação ex post de seu domínio. Como foi teoricamente provado pelo clássico livro de Hayek (1944), a escolha de determinado tipo de valores e prioridades predetermina também os modos e meios que culminam em um Estado totalitário e em uma economia de comando como seu subsistema. E, de fato: onde quer que tal experimento foi lançado, da Argélia a Nicarágua, a tendência foi incontestavelmente emergindo, mesmo que nem sempre tenha vencido. Por essa razão, tanto a industrialização forçada quanto o planejamento diretivo e o totalitarismo deveriam ser tratados como excessos parciais ou particulares de uma idéia fundamentalmente boa. Além disso, eles não devem, ou não deveriam, ser criticados por si mesmos, isolados de outros aspectos da totalidade sistêmica, como categorias ideologizantes - por exemplo, o socialismo de Estado/soviético, estalinismo, superindustrialização ou supercentralização.

Com relação à Europa Central e Oriental, contudo, a industrialização socialista não significou um caminho de modernização escolhido pela ação coletiva de cada um dos países e de todos eles. Foi a divisão da Europa, em Yalta, pelo grande poder pós-guerra o fator decisivo na determinação dos limites geográficos (e oportunos) das fronteiras do sistema socialista na Europa. É importante que, não apenas as fronteiras que às vezes cruzaram nações, como ocorreu na Alemanha, mas também que os países da Europa Central e Oriental foram artificialmente homogeneizados, por terem sido integrados ao império soviético. Esse fato foi decisivo na determinação de várias características de seu destino:

- suas relações comerciais, tradicionalmente voltadas para o Ocidente, após 1948 foram redirecionadas para o Oriente;

- o que prevaleceu não foi apenas a orientação geral do bloco oriental, mas a orientação soviética em particular. Isso significa que, apesar de muita retórica sobre a integração socialista multilateral, a relação permaneceu basicamente bilateral soviético-polonesa, soviético-búlgara etc., com a relação russa tendo respondido por dois terços do comércio total do Comecon ou CMEA (Conselho de Mútua Assistência Econômica [N.T.]), realizado pelos países da Europa Central e Oriental;

- certas mudanças nas políticas econômicas, especialmente as mais importantes, ocorreram quase que simultaneamente. Isto se aplicou às políticas mais voltadas ao consumidor do período 1953-55, à coletivização da 
agricultura em 1959-61, aos projetos de aceleração do crescimento no início dos anos 60 e durante os anos 70. Por volta da década de 80 , uma dessincronização tornou-se observável, refletindo a fadiga do mecanismo de coordenação imperial (o Tratado de Varsóvia, o CMEA, mas principalmente os contatos intrapartidários de primeiro escalão);

- relações econômicas externas, especialmente vis-à-vis o processo de integração européia, o FMI e os EUA permaneceram sob supervisão soviética até o final dos anos 80 . Os interesses econômicos foram subjugados a considerações de política externa (6);

- infra-estrutura institucional (7), qualitativamente similar existiu durante décadas, tendo assim produzido surpreendente grau de similaridades comportamentais em países que, de outra forma, seriam tão distantes como a Alemanha Oriental e a Bulgária. As tendências rumo à autosuficiência e à centralização de padrões organizacionais, ou as estratégias defensivas das empresas e sua aversão à inovação são características bem pesquisadas desse caminho de desenvolvimento. Em outras palavras, padrões típicos de países atrasados difundiram-se também em so-ciedades historicamente mais avançadas, como ocorreu nos Estados bálticos;

- fazer parte do império externo significou um padrão de desenvolvimento completamente diferente para a Europa Central e Oriental, em contraste com o que significou a conquista total para os Estados bálticos. Estes últimos não foram apenas politicamente sovietizados, mas também incorporados ao espaço econômico soviético único. Lembrando a então bem recente memória da monarquia austro-húngara, Stálin não quis reproduzir uma situação na qual dois terços da população não estariam interessados em manter o Estado/constructo unido. Portanto, ele e seus sucessores resistiram intencionalmente à tentação de integrar qualquer uma das nações conquistadas (8). Em vez disso, seguiram o padrão bizantino de poder, de criação de dependências radiais. Tal princípio conhecido como centralismo democrático nos partidos comunistas - significa que somente contatos verticais são legítimos, e qualquer tentativa de se criar subgrupos é considerada alta traição. Incidentalmente, quando o ex-Secretário Geral do Cominform, Georgi Dimitrov, esqueceu essa máxima em sua condição de líder búlgaro, e criou uma união alfandegária com Tito em 1948, foi duramente criticado pelos russos e morreu, após algumas semanas, em condições misteriosas (Berend, 1971). Essa experiência foi instrumental no estabelecimento do padrão das relações intra-CMEA. Por um lado, o modelo soviético de planejamento diretivo teve que ser importado e copiado. Por outro, não pode ser generalizado. Economicamente, isso teria significado a imposição de um planejamento supranacional dos mercados nacionalmente segmentados. Mas tal procedimento iria contra a máxima imperial já descrita. Ir em direção oposta, ou seja, por meio do mercado, pressuporia o funcionamento de mercados verdadeiros dentro das economias constituintes. Mas 
uma variante socialista radical de mercado estaria em desacordo com o domínio do partido único (sem falar de mercados privados). Assim, a opção pelo mercado ficou igualmente fechada. E este permaneceu sendo o paradoxo fundamental do Comecon durante toda a sua existência. Como documentado em Csaba (1990), a pulsação entre as extremidades igualmente fechadas do túnel, a integração (9), isto é, através de planejamento ou do mercado, contribuiu consideravelmente para a decadência do comunismo. Em termos práticos, foi a óbvia impossibilidade de reformar um Comecon antiquado, funcionando mal, que convenceu Gorbachev sobre a necessidade de abandonar o império externo;

- o tipo de estratégias econômicas domésticas que poderia ser seguido na Europa Central e Oriental foi, assim, em grande parte, predeterminado pelas exigências já descritas. De uma perspectiva sistêmica, a inclusão em um ambiente planejado/planejável foi pré-condição para a viabilidade do planejamento macroeconômico em pequenas economias abertas. Do lado da entrada (input), os contratos intergovernamentais obrigatórios de longo prazo (cinco anos) garantiam importações dos bens não-disponíveis domesticamente, necessários para estabelecer balanços macroeconômicos. Do lado da saída (output), os mercados planejados garantiam a venda da produção das novas capacidades criadas. Quase que imediatamente após sua instalação, esse mundo artificial ganhou vida própria, criando interesses e estruturas que se reproduziram a si mesmas e "vantagem socialista comparativa", além de resistência às mudanças estrutural e institucional (Hillman \& Schnytzer, 1992).

Esse contexto explica a maioria das decisões políticas, dos dilemas e dos padrões de desenvolvimento reais de todo o período socialista. Casos excepcionais à parte, a interferência operacional soviética era negligenciável na conduta real dos afazeres, como na escolha das opções entre determinados projetos alternativos de grandes investimentos ou na determinação de prioridades setoriais ou organizacionais. Esses aspectos explicam em grande medida a considerável diversidade existente em cada país da Europa Central e Oriental. Por exemplo, os excessivos desequilíbrios gerados pelos planos de investimento incompetentes da Polônia nos anos 70 contrastavam nitidamente com a estabilidade financeira interna e externa preservada de forma contínua pela ex-Tchecoslováquia.

Mas, apesar de muitas diferenças, certas similaridades inerentes ao padrão do esforço de modernização tornaram-se evidentes. Sob uma perspectiva desenvolvimentista, não surpreende, nem constitui objeto de crítica afirmar: as prioridades de investimento dos países da Europa Central e Oriental não foram determinadas por considerações de retorno econômico. Em termos mais estabelecidos, isso significa a condução de politicas de substituiçãa de importaçães voltadas para dentro (10), bem como uma conseqüente negligência a considerações de mercado. 
Tanto histórica quanto logicamente, a opção pela economia de comando derivou de um desejo de estabelecer as prioridades estruturais e de desenvolvimento de modo autônomo. Como explicitamente declarado nos debates sobre a industrialização, o sistema tinha como objetivo implantar uma política para realizar um ideal e atingir as metas dele derivadas, isto é, por definição indisponível no ambiente corrente. Porém, uma vez introduzido o sistema estava fadado a exercer uma retroalimentação nas prioridades que os governos poderiam escolher "autonomamente" ou considerar racionais em sua própria lógica. Ou seja, somente projetos que se ajustassem ao mundo artificial do Comecon e preços planejados seriam viáveis.

O sistema foi moldado para suprimir qualquer retroalimentação, fosse do mercado ajustando preços, fossem sinais do mercado de capital ou, mesmo, mais reações do ambiente externo (capitalista) considerado, por definição, como hostil às metas mais "nobres" dos idealizadores do sistema. O monopólio sobre o comércio exterior e a moeda estrangeira, a fixação centralizada de preços e rendas, a alocação governamental dos investimentos e a incorporação em um ambiente planejado constituem, no conjunto, um sistema coerente (11). Tal sistema alimenta mais as prioridades que a ele se ajustem, do que aquelas que o transcendem. Como a lógica interna e externa ao sistema é diferente, poderia ser mera coincidência a demanda do mercado mundial e a oferta de produtos/produção endógenos das economias burocráticas serem coincidentes. Em outras palavras, a competitividade internacional cada vez menor da Europa Central e Oriental foi edificada pela escolba do modelo de desenvolvimento. Em uma das primeiras (e até o momento a mais lúcida) análises do sistema, Mises (1920) enfatizou corretamente: se o capital (e conseqüentemente outros fatores) não tiver correta valoração, o cálculo e as decisões corretas de investimento se tornam impossíveis. Portanto, além da falta de competitividade, a falta de eficiência e o correspondente estado de atraso com relação à competição global também foram conseqüências inerentes das opções originais.

Tendo levantado as repercussões sobre a inovação, a eficiência e a competitividade, ou seja, os principais aspectos do sucesso econômico, dúvida-se até que ponto tal caminho de desenvolvimento pode ser chamado de modernização. Como já mencionado, a sociologia clássica oferece bons argumentos para definir a modernização como um processo que promove a congruência com as condições prevalecentes nas sociedades mais avançadas. O levantamento das principais, especialmente sua forte interligação, adverte contra a descrição do período socialista na Europa Central e Oriental nesses termos.

A posteriori, é menos possível ainda interpretar-se a industrialização socialista como uma forma de modernização real, quando se permanece dentro dos limites mais técnicos da economia. Em primeiro lugar, fomentar uma expansão industrial numa época em que os países da OCDE entravam na fase da sociedade pós-industrial era incorrer em um atraso de cerca de 50 anos, especialmente no padrão estrutural dos países mais avançados da Europa Central. Em segundo, a 
ênfase no investimento como a única fonte de crescimento parece extremamente simplista. A teoria econômica já apontou para a decisiva importância de outros fatores, primariamente organizacionais e motivacionais, bem como da mudança tecnológica endógena (12), no estímulo ao crescimento em meados dos anos 50 (Solow, 1956). A análise mais recente, de aproximadamente 100 países, por meio de um modelo de regressão, indica antes uma ligação causal oposta: somente um crescimento suficientemente elevado gera as fontes/rendas para a manutenção de taxas suficientemente elevadas de investimento (Blomström et al., 1993). Em terceiro lugar, qualquer que seja a opinião sobre o inter-relacionamento entre investimento e desenvolvimento, qualquer tentativa que se concentre em um único fator e desconsidere a possível contribuição de outros, como infra-estrutura, questões sistêmicas e capital humano, para não falar nas complexidades do equilíbrio ecológico e da sustentabilidade, deve ser considerada simplista, mesmo pelos padrões contemporâneos.

Mas nosso argumento mais forte, contra a interpretação da modernização, é o quarto, isto é, a incapacidade prolongada do sistema socialista de se ajustar ao mundo em transformação pela via da auto-reforma. Isso é ainda mais surpreendente, na medida em que as deficiências inerentes tanto às decisões estratégicas quanto às sistêmicas tornaram-se evidentes desde o início. $\mathrm{O}$ Comunismo de Guerra foi um desastre imediato. O primeiro Plano Qüinqüenal da Rússia produziu a fome de 1930/1931. Na Hungria, o primeiro plano qüinqüenal de 195055 teve que ser substancialmente modificado por duas vezes, em 1951 e em 1953 , e em diferentes direções. Portanto, os clamores por reforma têm a mesma idade que o próprio experimento socialista. Além disso, em vários países, o socialismo clássico, conforme praticado na Romênia e na Alemanha Oriental durante 40 anos, sobreviveu durante alguns anos apenas como digressão; na Iugoslávia somente entre 1946-1952; na Hungria, entre 1949-1953; na China em 1949-65. A Polônia nunca foi um bom exemplo, já que nem o monopólio ideológico nem a agricultura coletiva puderam ser impostos a este país .

Não cabe aqui reiterar a história das reformas com todas as suas cores (para uma narrativa, cf. Adam, 1993). O central a elas relacionado - bem como em qualquer reforma - é a tentativa de mudar, se necessário, qualquer componente da estrutura com o intuito de manter o constructo subjacente. Este, no caso da Europa Central e Oriental, implicou quatro elementos básicos: determinação autônoma de objetivo; domínio do partido único; predomínio da propriedade pública e coordenação burocrática; finalmente, aliança com a Rússia; isto é, respeito às fronteiras e ao status de império externo (13).

A determinação autônoma de objetivo implicou em que todas as principais decisões de investimento continuassem nas mãos das autoridades. Embora as empresa pudessem - muitas vezes com sucesso - influenciar tais decisões em barganhas burocráticas e lobbies, a palavra final continuou sendo das autoridades oficiais. Por isso, o monopólio do comércio exterior teve que ser mantido e não foi possível introduzir em parte alguma a conversibilidade da moeda. 
A contestação de concepções tornou-se parte da normalidade política. Entretanto, ela nunca pôde irromper abertamente na forma da clássica disputa de partidos. Nos países em que era permitida a atividade de mais de um partido, estratégias alternativas nunca afloraram à superfície com os partidos satélites, como os democratas cristãos da Alemanha Oriental, por exemplo: elas sempre se originavam no interior do Partido.

Houve florescimento da economia informal, bem como de várias formas de atividade privada e semiprivada abertamente reconhecidas; mas elas nunca se tornaram dominantes (nem mesmo na Polônia). Por fim, nem por isto menos importante, enquanto o Comecon existiu, ele serviu como garantia da preservação de "realizações socialistas" na economia, da mesma forma que o fez o Tratado de Varsóvia em termos geopolíticos.

A tão tênue definição dos limites para as reformas não tem a intenção de menosprezar seu significado. Quanto maior foi o período de reformas, e mais amplo o seu alcance, melhor a preparação das sociedades da Europa Central e Oriental para a transformação sistêmica e maior a sua receptividade aos resultados de mercado e às instituições de mercado. Num extremo, o Parlamento Russo decidiu, em julho de 1994, manter a exclusão da transferência da terra da lei de privatização. No outro extremo, na época em que a Eslovênia se tornou independente, a privatização já estava bem em curso e a conversibilidade da moeda pôde ser introduzida da noite para o dia por uma equipe bem-treinada e tecnicamente sofisticada do Banco Central. Na Belorus, a ausência de reformas era tal que a penúria rapidamente levou o eleitorado a apoiar abertamente as políticas estatizantes/neoestalinistas. Em contraste, na Polônia o reconhecimento das mudanças foi tão intenso que a aliança da esquerda com o setor agrário basicamente deu seqüência à política de Balcerowicz, com o mesmo vigor financeiro, após a sua vitória em setembro de 1993.

Analisando com maiores detalhes, as reformas socialistas foram úteis não meramente como instrumento para tumultuar a coerência do sistema de comando e dessacralizar os tabus; elas treinaram dezenas de milhares de pessoas no aparetho do Estado, bem como milhões de familias nas artimanhas e reviravoltas do mercado. Quando a poupança em moeda forte se torna uma opção e ativos fixos podem ser comprados, a poupança não é meramente uma função das taxas de juros ditadas pelo Banco Central; a administração da carteira torna-se uma opção para a família média. Quando as empresas precisam cuidar dos lucros, mesmo antes de serem privatizadas, ocorre uma mudança corpernicana de mentalidade: todos aprendem que o "dinheiro faz o mundo girar" e as estruturas produtivas físicas, e mesmo o emprego, são secundários. Onde a economia informal teve uma longa história, pertencer à hierarquia oficial tornou-se apenas uma entre várias opções competitivas de carreira. Por isso, as pessoas melhor preparadas nem mesmo participaram dessa corrida. Em outras palavras, estas últimas sociedades não foram muito abertas à engenharia social, porque as pessoas tendiam a se importar mais com seus próprios negócios, não esperando do governo nada além de não-interferência. Por outro lado, nos países sem experiência de 
reformas, como a ex-Tchecoslováquia, a sociedade pode ter maiores expectativas e dar maior apoio aos engenheiros sociais.

$\mathrm{Na}$ literatura sobre as transformações sistêmicas, discute-se freqüentemente que as reformas não foram apenas um jardim de rosas, ou seja, não apenas ajudaram, mas dificultaram a criação de uma verdadeira economia de mercado na Europa Central e Oriental. De certa forma, é também verdadeiro que um sistema sem reforma alguma, como o da ex-República Democrática da Alemanha, constitui o melhor terreno para a introdução de algo diametralmente oposto a ele. As reformas, devido à sua tibieza e por serem as segundas melhores (second best) opções, criaram complexidades, como direitos à propriedade imprecisos e ausência de clara delimitação entre os bons capitalistas e a má nomenklatura. As reformas devolveram direitos sem responsabilidades, criando, por exemplo, bancos comerciais sem critérios estritos de prudência e correta supervisão, ou empreendendo o gerenciamento corporativo, sem forçá-lo a colocar em risco pelo menos parte de sua própria propriedade.

Cada uma dessas afirmações traz um quê de verdade. Entretanto, é importante não ser iludido por uma dose excessiva de teoria de livro-texto. Para a ciência social, em geral, e a moderna teoria econômica formalizada, em particular, a coerência é uma máxima suprema, no mínimo por razões técnicas. Para a prática social, a exeqüibilidade pode ser mais relevante. Se se abrir caminho para modernas abordagens dinâmicas na modelagem política, a sustentabilidade, a credibilidade e a construção de coalizão deverão surgir no cenário como ingredientes relevantes para uma linha política que pode ser mantida estável durante longo período de tempo.

Sob esse ângulo, a despeito de todas as limitações e contradições internas, as reformas foram extremamente úteis;

- elas voltaram as percepções públicas em direção à complexidade dos problemas, para a qual nenhum modelo de questões isoladas pode oferecer resposta: a preocupação com questões isoladas foi precisamente uma das características das reformas parciais;

- de fato criaram partidários da reforma, organizações e grupos sociais com participação no mercado;

- ajudaram a dispersar vários, de uma lista interminável, mitos criados pelo experimento socialista, desde a idéia de preços justos até a capacidade de o governo definir posições pré-fixadas de renda para certos grupos da população;

- tal postura poderia ser chamada de atitude socialmente receptiva aos resultados do mercado, disposição para tolerar desigualdades;

- as mudanças políticas não evitaram que se buscasse segundas (second best) opções . 
Por exemplo, na reestruturação empresarial, e também na privatização, a busca de direitos de propriedade claramente delineados conflita com a necessidade de confiar no conhecimento gerencial inerentemente descentralizado. A julgar pelas experiências polonesa (Dabrowski, 1994) e húngara (Voszka, 1994), as ambições governamentais de prefixar aquilo que é inerentemente efeito ex post do jogo de mercado (e.g., quem são os vencedores ou os proprietários) acarreta graves perdas da eficiência e tolhe a modernização corporativa. Conseqüentemente, as reformas podem induzir os políticos e igualmente o público a aceitar aquilo que poderia muito bem ter sido aprendido das novelas clássicas francesas, russas e alemãs: a riqueza e a virtude não são necessariamente irmãs gêmeas.

De uma perspectiva prática, contudo, a dose excessiva de reformismo não é o legado mais pesado dos países da Europa Central e Oriental. Na verdade, o fardo real refere-se à perda dos anos 70 e 80 para o ajustamento. Quando o potencial do modelo de industrialização para alcançar os países mais avançados esgotou-se por volta do final dos anos 60 - foram encontradas duas respostas típicas. Em alguns casos, a reforma foi o isolamento: uma política de autoconfiança nacional - e, adicionalmente, regional - foi fomentada. A Tchecoslováquia, nos anos $70 \mathrm{e}$ 80, e a Romênia, nos anos 80, são exemplos disso. Alternativamente, o cultivo de relações comerciais e financeiras mais intensas com o Ocidente foi utilizado para atenuar os gargalos. Nesse aspecto, a União Soviética e a Alemanha Oriental constituem os principais exemplos, especialmente nos anos 80. No último caso, a abertura limitada serviu como substituto das reformas. Nos dois exemplos, os padrões de produção doméstica, as estruturas de poder e os arranjos não-competitivos em geral puderam sobreviver nitidamente.

Interpretando o desenvolvimento de nosso referencial analítico pelo "sucesso na desmodernização", a distância da Europa Central e Oriental com relação aos padrões da OCDE só aumentou em todos os planos dignos de nota. A falta de possibilidade e de disposição para ajustar-se ao seu ambiente em mutação pode ser letal para qualquer organização. Foi demonstrado que as razões para a ossificação foram mais estruturais do que coincidência ou geradas pela política. Portanto, duvida-se da relevância do fator Gorbachev no desencadeamento do colapso.

De fato, à época da ascensão de Gorbachev ao poder, o impasse da modernização tinha se tornado lugar-comum político na Rússia. Na realidade, o mentor do grande reformador, Andropov (1983), não poupou esforços para deplorar os sinais da corrosão global na sociedade soviética contemporânea. Como ex-chefe da polícia secreta - KGB -, o centro de poder onipresente, ele deveria ter conhecimento do que ocorria. À época em que Gorbachev pôde assumir o poder, em 1985, a oportunidade para as reforma já estava exaurida. As imensas e fáceis receitas de um novo choque dos preços do petróleo, que ele esperava para o inverno de 1984/1985, nunca se materializaram. Conseqüentemente, Gorbachev estava tentando dirigir um velho automóvel ao qual faltavam os grandes volumes de petróleo que o motorista anterior tinha à disposição. 
Gorbatchev tentou introduzir as reformas parciais dos anos $60 \mathrm{com}$ um atraso de duas décadas. Mas era tarde demais: mesmo introduzidas, não abordaram os fundamentos do impasse da modernização. Sem reiterar uma visão geral detalhada de suas reformas (Csaba, 1992), basta observar: nenhuma das medidas contempladas (14) - muito menos aquelas realmente implementadas - estava atingindo os elementos centrais seja do modelo, seja da estratégia que repousam no coração do impasse da modernização.

Portanto, não é surpreendente que as reformas soviéticas tenham sido radicais somente no vocabulário. Ao contrário de seus pares chineses, Gorbachev não pôde contar com uma reforma espontânea importante, iniciada de baixo para cima, nem com influxo maciço de investimento direto estrangeiro dos expatriados. Assim, ele não pôde capitalizar a dinâmica de reformas parciais, que complementassem e corrigissem uma postura macroeconômica hesitante (Chen et al, 1992; Perkins, 1994). Gorbachev não teve predecessores - como Deng teve Mao - que desmontassem, desorganizassem e desmoralizassem o todo-poderoso Partido e os aparelhos estatais. Em vez disso, uma sufoco gradual cresceu até chegar ao colapso, inicialmente na periferia e, mais tarde, também no centro do país.

Quais as lições desse resumo rudimentar dos eventos ocorridos? Primeiramente, que os problemas existentes na Europa Central e Oriental foram bem mais graves do que implicariam - digamos - a desaceleração no crescimento, $o$ incremento na relação capital/produto incremental no endividamento ou as insuficientes exportações. A Europa Central e Oriental sofre de uma crise de modernização multidimensional. Todo o seu padrão de desenvolvimento - societário, econômico, tecnológico, educacional e motivacional - é insatisfatório sob a perspectiva dos mercados globais; quer essas economias estivessem desestabilizadas (como a Bulgária) ou não (como a ex-Tchecoslováquia), quer não tivessem dívidas externas (como a Romênia) ou as tivessem muito elevadas per capita (como a Hungria), todas elas estavam na mesma situação. Por esta exposição deve se ter esclarecido que a estabilização, que pode ou não ser necessária em qualquer país em desenvolvimento, ou o ajustamento em conta corrente, que pode ou não ser necessário também nos países avançados, correspondem à superfície dos problemas que afligem a Europa Central e Oriental. Portanto, aquele importante corpo de literatura e de assessoria internacional que se originou nas teorias de estabilização do FMI (Fundo Monetário Internacional) e na experiência latino-americana, tem se revelado equivocado (15). Pois, por mais importante que possa ser a reconquista da solvência, especialmente no curto prazo, ela é questão menor se comparada à de enfrentar e resolver o impasse da modernização. Por esse motivo, a ideologia do um "salto no mercado" deve ser considerada como inerentemente contraproducente. Não é possível enfrentar, e muito menos resolver, o tipo de problemas discutidos neste tópico em período de seis a nove meses. Os intelectuais e consultores, que despertaram falsas expectativas quanto a uma rápida recuperação, dividem a responsabilidade pela crescente resistência das sociedades desiludidas (16), que se voltaram para os partidos de esquerda ou 
de extrema direita em meados dos anos 90. Um nacionalismo ressurgente no nível governamental é outro sinal da falta de resposta às questões básicas da modernização. A promessa do desenvolvimento para equiparar os países atrasados aos mais avançados não foi cumprida, mas, não foi descartada.

\section{Transformação como um novo caminho da modernização}

Do que já foi discutido, percebe-se que os problemas e as tarefas políticas enfrentados pelos países da Europa Central e Oriental são multidimensionais e multifacetados. A complexidade da situação, a extrema diversidade de opiniões, bem como a habitual falta de clareza na literatura em crescimento exponencial sobre o tema, têm a ver com a presença simultânea de varias questões, qualitativamente diferentes, que emergiram na região. Para se analisar a transformação como novo caminho para a modernização, parece prudente deixar de lado os problemas da estabilização, que são similares aos temas discutidos nos países em desenvolvimento. Da mesma forma, os problemas gerais das políticas macroeconômica e de comércio externo judiciosos não precisam ser aqui repetidos. Assim, nossa discussão cobre somente os problemas de mais longo prazo, a construção institucional, as mudanças nas normas comportamentais, ou seja, questões relacionadas ao novo caminho da modernização - a tarefa a ser realizada para sair do impasse.

Como a crise que desencadeou a mudança sistêmica originou-se não somente de uma peculiar mescla política ou de um peculiar conjunto de instituições, mas abarcou a totalidade socio-econonômica, era correto se esperar perdas duradouras e consideráveis tanto da produção quanto do emprego, que - de acordo com os dados apresentados nas tabelas anexas - de fato se materializaram (17). Dois comentários podem ser pertinentes nesse aspecto. Primeiro, a queda foi inevitável e, em vários sentidos, não apenas previsível, mas favorável (Winiecki, 1991), uma vez que a erradicação da produção e do emprego desnecessários realmente elevam o bem-estar e eliminam o desperdício. Segundo, não é apenas a notória falta de confiabilidade das estatísticas locais que explica a excepcional incerteza sobre o macrodesempenho real. Dadas a distorção anterior dos preços e as relações insumo/produto freqüentemente singulares, explicadas pela escassez, o interesse nos aumentos de custo, a insensibilidade com relação ao uso de insumos, a inépcia burocrática, o entesouramento ou a simples ignorância dos mercados externos, é possível que os macroindicadores e o bem-estar público estejam apenas fracamente relacionados, se tanto. No caso da Rússia, por exemplo, é possível apresentar exemplo razoavelmente convincente (Aslund, 1994) de um aumento considerável no consumo em 1993-94 enquanto o PIB despencava, porque o setor de defesa afundava a profundidades desconhecidas, a produção nos setores civis aumentava consideravelmente. Nesse caso, a normalização das deformações anteriores pode supercompensar as perdas no PIB e a mudança estrutural ser mais significativa que as tendências do produto bruto. 
Os níveis anteriores de produção e emprego estavam intimamente relacionados com o mundo protegido do Comecon, conforme descrito no tópico anterior. Como este era um padrão desmodernizado inviável, a reconquista dos niveis anteriores à crise não parece fazer muito sentido como indicador de sucesso. Por exemplo, quando na União Européia os níveis de desemprego se situam em 11\%, não é uma proposta séria esperar que as economias da Europa Central e Oriental sustentem níveis de emprego mais elevados que esse, antes de terem completado seu reajuste (que não é um tipo de correção cíclico). O nível de desemprego antes da crise era zero e, conseqüentemente, a aplicação deste padrão pode levar a demandas insaciáveis. Da mesma forma, os níveis de produção em vários setores eram insensatos, como na mineração de lignita na ex-República Democrática da Alemanha. Ninguém em sã consciência proporia a recuperação dos picos de produção da lignita do final dos anos 80 , como uma medidade de terem ou não as províncias da Alemanha Oriental superado a sua crise. Em resumo, as categorias clássicas da teoria dos ciclos não parecem particularmente úteis na interpretação do desenvolvimento na Europa Central e Oriental.

Uma vez iniciado o ajuste no setor de defesa, e conseqüentemente nas indústrias a ela relacionadas, em seguida o comércio intra-Comecon artificialmente inflado e setores correlatos em cadeia, todos estavam fadados a reduzir-se irrecuperavelmente. Por esse motivo, só se poderia esperar por um multiplicador keynesiano negativo em operação. Deve-se lembrar: uma vez que novos perfis viáveis não são conhecidos em sua totalidade, e que a não-utilização de capacidades competitivas era, por definição, impossível sob o regime socialista, o espaço para a administração clássica da demanda pelo Estado não existe. A experiência internacional, como os experimentos francês e grego nos anos 80, evidencia a possibilidade muito limitada de aplicação das antiquadas receitas de administração da demanda em economias pequenas e abertas. Nos países em transformação isso se sustenta a fortiori. De fato, aqueles países em que a demanda macroeconômica foi artificialmente fomentada por emissões de credito, como ocorreu na Ucrânia e na Belorus, sofreram mais e por mais tempo. Enquanto isso, a recessão transformacional chegou ao fim, inicialmente na Alemanha Oriental, depois na Polônia e finalmente na Hungria e na Tchecoslováquia em 1991-94.

Encontra-se com freqüência comparações entre perdas correntes de produção e as ocorridas durante a Grande Depressão de 1929-33. Tal perspectiva parece fundamentalmente equivocada. Naqueles anos, os países pequenos enfrentaram um protecionismo internacional geral, ao passo que os mercados internacionais não se reduziram nos anos 90 . A conversibilidade da moeda foi mantida. Enquanto isso, a Europa Central e Oriental não enfrenta meramente uma crise de demanda sufocante, mas um conjunto de crises, de reorientação estrutural e de ajustamento, que, se somadas, não são senão um dos componentes - o econômico - no impasse global da modernização. Em resumo, o necessário nãa é mais produção, mas uma produção diferenciada, produzida e vendida sob diferentes métodos. Ainda não se sabe onde estão as novas fronteiras da produção. Ainda não se sabe sob quais condições emergem os novos equilíbrios. 
Somente uma coisa é certa: nenhuma delas pode e deve ser medida considerando-se os níveis anteriores à crise.

Assim, é difícil compartilhar a avaliação cada vez mais popular de analistas influentes (Herr et al, 1992; Kolodko, 1992) colocando a promoção no crescimento do cerne de todo o exercício transformacional. Obviamente, todo o resto permanecendo constante, um bolo maior garante que mais bocas serão alimentadas. Mas o lamentável estado de coisas é caracterizado precisamente pelo fato de todos os outros fatores não serem constantes. O crescimento no macronível é uma derivada de muitas interações, que são dificilmente sujeitas à direta calibração governamental - isso é claramente evidenciado pela falência do planejamento macroeconômico. Portanto, as políticas governamentais podem apenas aspirar apenas a influenciar fatores e circunstâncias que levam ao crescimento (mais precisamente: desenvolvimento sustentável). E esta não é tarefa fácil, especialmente se as incertezas forem numerosas e as cadeias na ligação causal somente em casos excepcionais se seguirem imediatamente. É difícil visualizar qual será a conseqüência real de determinada medida, quando houver necessidade de desistir de modelos nos quais os fatores indesejados podem ser explicitamente abstraídos, e quando houver necessidade de reduzir as abstrações no curso de uma tomada de decisão política.

Nessa perspectiva, é importante fazer um levantamento das restrições de longo prazo ao crescimento econômico na Europa Central e Oriental. Mesmo abstraídas das crises já discutidas, as limitações são flagrantes. Escassez de capitale o antiquado estado dos ativos fixos e da tecnologia, assim como a falta de capacidades gerenciais pertencem aos axiomas de qualquer descrição da região. Em teoria, pode-se considerar que o trabalho é abundante e subutilizado. Entretanto, quando considerado sob o ângulo prático dos investidores, concentrado na competitividade internacional e não nas categorias formais muitas vezes enganosas da educação, o trabalho também se transforma em item escasso. O recrutamento de mão-de-obra qualificada, motivada e capaz de desempenhar-se de acordo com os padrões internacionais, tornou-se problema constante, mesmo para joint ventures, que oferecem salários exorbitantes em termos locais. Por outro lado, o mineiro, o metalúrgico ou o professor de história do Partido Comunista podem não ser as únicas redundâncias, que possivelmente nunca conseguirão um novo emprego.

O solo poderia, em teoria, ser considerado um ativo; mas, conhecendo a gravidade da decadência ecológica da região, bem como o constante excesso de oferta de produtos agrícolas nos mercados mundiais, tal fator não parece ser muito dinâmico. Finalmente, nem por isso menos importante, as inovações podem trazer a luz no final do túnel. Se implicar em inovação de produto, então exigirá investimento, especialmente dos países avançados; este estará disponível em quantidades limitadas (18) pois as poupanças domésticas não podem ser mantidas artificialmente tão elevadas quanto costumava ser o "padrão" do período socialista. Se significar inovação organizacional, equivalerá à mudança institucional, que será discutida a seguir. 
Tudo considerado, a mudança institucional ou o componente sistêmico continuou sendo o unico principal fator do crescimento de longo prazo da Europa Central e Oriental. Este é o caminho para melhorar a eficiência alocativa - no curto e no médio prazos - e igualmente acelerar o progresso tecnológico endógeno que, na moderna teoria do crescimento, é o principal determinante do crescimento de longo prazo. O único problema é saber que esse fator exerce seu impacto benéfico somente a médio e longo prazos.

Desta forma, chega-se mais perto de circunscrever o que significa a transformação do sistema em termos positivos. Como já foi visto, é possível que a estabilização e o ajustamento em conta corrente sejam prelúdios necessários para que o processo decole. Uma economia desestabilizada está mais propensa a se tornar caótica do que a evoluir rumo à ordem de mercado. A liberalização, especialmente a liberalização do comércio exterior, pode ser componente importante na construção de uma ponte entre as considerações de curto prazo (de estabilização) e as de longo prazo (de transformação). Essa é a maneira de controlar os relativos de preços domésticos, a maneira de expor os agentes à competição. Especialmente em países pequenos, a propensão à cartelização é elevada e, conseqüentemente, um regime protecionista de comércio constitui maneira fácil de os produtores e sindicatos se esquivarem da competição e de manterem as condições de desinteresse de uma sociedade que barganha.

Os perigos inerentes a essa opção são sombrios uma vez que, ao contrário dos países nórdicos, as economias da Europa Central e Oriental não são fundamentalmente competitivas nos mercados internacionais. Depois de várias décadas de isolamento, ninguém pode realmente dizer qual deveria ser o padrão econômico ótimo nos países em transformação. De fato, varias tentativas feitas por analistas de grande projeção, para calcular onde estaria a vantagem comparativa dos europeus centrais e orientais, resultaram em proposições paradoxais. Mais freqüentemente, que o contrário, os maiores perdedores reais, como as usinas de aço eslovacas ou a produção húngara de trigo, pareciam ter vantagem (até que a competição de mercado corrigiu tais suposições, um tanto ingênuas).

Uma questão muitas vezes levantada (e.g., Rosati, 1994) é a de que mercados fracos precisam ser suplementados ou complementados por politicas industriais ativas do Estado. Faz-se referência freqüente a vencedores selecionados dos novos países em industrialização, e ao caráter de curto prazo dos mercados (ou sua organização oligopolista). Embora a discussão do tema esteja próxima de um debate sobre convicções religiosas (Glaubensstreit), basta observar que a Europa Central e Oriental está saindo de um estágio, no qual o funcionamento cego do mercado não foi exatamente decisivo, tendo moldado durante décadas os padrões de produção atualmente disponíveis. Além disso, o setor público, especialmente na indústria, continuou importante, mesmo depois de vários anos de privatização. A idéia de que uma visão governamental constituiria base melhor para as principais decisões estruturais de vencedores selecionados do que qualquer outra, não parece particularmente esclarecedora ou convincente após as décadas de economia planejada. Por outro lado, a não ser que se suponha um 
governo muito forte e esclarecido, os defensores dos modernos conceitos de política industrial também reconhecem os perigos inerentes à aplicação dessa idéia em um ambiente sem mercado. É o caso, por exemplo, de uma grande administração sem transparência e subqualificada dirigir um setor industrial ou bancário poderoso e não muito marginalizado politicamente, típico na Europa Central e Oriental. A evolução das reformas russas, especialmente após as eleições de dezembro de 1993, ilustram claramente este ponto; mas observações semelhantes podem ser feitas nos casos da Romênia e da Bulgária. Em ambos os países, a privatização e o desenvolvimento da intermediação financeira tornaram-se claramente subordinados ao interesse industrial. Conhecendo os exemplos do Japão e de outros países do Leste Asiático, esse desenvolvimento não surpreende muito, mas sua réplica é indicativa das inter-relações causais diretas entre conceitos e conseqüências.

Esse aspecto nos leva a outra questão, que se refere à intermediação financeira e à ligação indústria-banco. Ninguém com formação econômica duvidaria do papel central dessas questões na modernização da estrutura e governança corporativas, especialmente se o modelo-alvo for qualquer espécie de mercado capitalista. O sistema bancário e de credito eram conhecidos como o sistema nervoso do capitalismo. Entretanto, quando se fala sobre a Europa Central e Oriental, os mercados de capital, mais precisamente os mercados de ações, são incluídos na agenda política. Muitos analistas declaram ser a criação desse elemento mais sofisticado da intermediação financeira contemporânea o cerne de todo o exercício transformacional.

Seguindo nossa linha de exposição, é difícil encontrar para tal abordagem uma justificativa que fosse resultante organicamente das disponibilidades materiais e mentais na região da Europa Central e Oriental. Se condições elementares para captar poupanças e transformá-las em investimentos não são criadas, é artificial e desnecessário especular sobre as opções mais sofisticadas do mercado de capitais. Para a reestruturação e modernização das empresas, são imprescindíveis dinheiro novo e boa governança corporativa (inclusive fiscalização).

Na prática das economias de mercado mais avançadas, os mercados de ações constituem uma questão lateral interessante no contexto da finança corporativa. Isto tem a ver com o fato de apenas as empresas maiores e mais destacadas qualificarem-se para ter as suas ações cotadas nas bolsas de valores. Por definição, nem os novos empreendimentos privados - que numericamente constituem o grosso das empresas na Europa Central e Oriental - nem os grandes elefantes brancos de propriedade estatal têm boa chance. Os empreendimentos privados não se qualificam porque são demasiadamente pequenos ou crescem muito rapidamente, estando assim propensos a um dos fracassos típicos de novos empreendedores: expansionismo excessivo e financeiramente pouco sólido. A Hungria tem a história mais duradoura desse tipo de empreendimento, produzindo incontáveis casos desse natureza. Entre 1992 e 1994, enfrentavam esses problemas muitos dos famosos astros da classe empresarial, tipicamente os capitalistas nacionais de médio porte com crescimento rápido, como a empresa de 
telecomunicações Kontrax, a empresa de aço Peko ou a corretora Lupis. Grandes empresas públicas reorganizadas são penalizadas com uma lucratividade média de 3-4\% na indústria. Será dificilmente casual que na Bolsa de Valores de Budapest, fundada em 1989, sejam negociadas ações de 30-40 empresas, quando o número de empreendimentos é maior que 1,14 milhões. O giro das ações permanece muito limitado e o estreito mercado é dominado por letras de tesouro e notas de restituição, isto é, tipicamente valores mobiliários estatais. É interessante que os pioneiros da privatização em massa não tenham conseguido introduzir a negociação de vouchers (cheques de privatização [N.T.]) na Bolsa de Valores de Praga.

Nessas circunstâncias, a maioria dos papéis das empresas é negociada muito abaixo de seus valores nominais, o que não é surpreendente. Os mercados são estreitos e as cotações excessivamente voláteis nas três bolsas de valores: Varsóvia, Praga e Budapeste. A experiência mostra que essas cotações têm valor limitado na avaliação das reais perspectivas do mercado de quaisquer empresas individuais ou da economia em geral. Na maioria das vezes, fatores coincidentes determinam as tendências em um mercado pequeno, no qual até a manipulação realizada por corretores individuais pode provocar sérias flutuações. A entrada inesperada de investidores estrangeiros, por exemplo, diversificando sua carteira ou fazendo uso de, digamos, regulamentações britânicas em lugar das novas regulamentações húngaras sobre dedução de impostos, produziu booms artificiais em 1992-94, exatamente quando indicadores econômicos e fiscais nacionais teriam justificado o oposto. Em resumo, a Bolsa Valores constitui um local de treinamento, interessante e instrutivo para muitas pessoas, mas, de modo geral, ainda está fadada a manter-se como questão lateral na transformação global.

Nesse caso, a modernização e a privatização do setor bancário tornam-se questões centrais. Embora os primeiros debates sobre a "transição" tenham sido desviados, seja pelas discussões sobre a estabilização, seja por controvérsias ideológicas sobre os direitos de propriedade e os modos de mudá-los, a intermediação financeira continuou sendo uma questão relativamente negligenciada. Isso constituiu um problema porque, para que a modernização fosse iniciada, duas tarefas tinham de ser cumpridas em qualquer caso: poupanças deveriam ser acumuladas em quantias suficientes, na forma de depósitos de longo prazo; estes deveriam ser transferidos aos empreendedores, que também precisam da prestação de serviços financeiros de varias espécies.

Nenhuma dessas tarefas são triviais sob condições de múltiplas incertezas, exacerbadas pela falta de confiança do público em ambas as instituições - tradicionais e novas. Por isso, enquanto nos EUA a existência de letras do tesouro de 20 anos é normal e mesmo uma forma lucrativa de poupança, na Hungria, com possibilidades diversificadas de investimento em carteira, os depósitos bancários continuaram predominantes, com um horizonte máximo de um ano (19). Títulos governamentais são comprados pela população - muito $\bullet$ menos por bancos e empresas - pois mesmo possibilidades de dedução fiscal extremamente generosas os tornam um negócio improvavelmente lucrativo. Embora seu retorno anual 
estivesse em torno de 65\% em 1994 (20) com o Índice de Preços ao Consumidor em torno de $20 \%$, ainda assim seria um investidor privado húngaro menos típico quem reestruturaria sua carteira de maneira a que os títulos do governos nela dominassem e - digamos - as contas monetárias menos lucrativas fossem abolidas.

Esse manifesto problema de credibilidade é restrição muito mais severa à modernização do que a escolha de tecnologias corretas para a transferência dos títulos de propriedade. Conforme indicou a primeira falência de uma instituição financeira, a do Banco de Valores Imobiliários da Hungria, em 1990, o negócio de transformar depósitos de curto prazo em crédito de investimento de longo prazo é extremamente arriscado. Mesmo sob a mais estrita e profissional autoridade bancária supervisora, o risco desproporcional de conceder créditos de investimento continua sem solução.

Suponha-se por um momento que nenhuma má dívida herdada constitui uma carga sobre o sistema bancário, uma vez que dessa dívida foi simplesmente dada baixa contábil logo no primeiro dia da transformação, seguindo a sugestão de Begg \& Portes (1993) (21). Nesse caso, é preciso cuidar somente dos novos créditos. No lado dos depósitos, encontram-se direitos tipicamente de curto prazo. No lado do ativo, tem-se: antigos clientes; novos clientes privados; aventureiros. A primeira categoria não é particularmente um bom risco, a menos que se possa contar com uma série de operações de consolidação industrial, com fianças generosas e regulares, como aconteceu na Hungria em 1992-94. Nesse caso, a categoria de risco moral não precisa de elucidação detalhada. Na segunda categoria inserir-se-ia um não-principiante com a maioria dos bancos ocidentais e com histórico de desempenho ou com muito bons colaterais. Os fundos de investimento são raramente equivalentes a sólidos bancos mercantis. Finalmente, a terceira categoria poderia fazer quaisquer promessas para deixar satisfeita qualquer pessoa que se importe mais com um pedaço de papel do que com julgamento ou credibilidade sólidos.

Acontece que, mais cedo do que acreditaria a maioria dos teóricos, voltase ao problema original da má dívida, mas desta vez sem os comunistas para serem por ela responsabilizados. De fato, na Hungria, já em 1992 e mais intensamente em 1993 e 1994, o grosso da má dívida (60, 80 e 90\%) foi se acumulado no setor privado ou por empréstimos concedidos nos anos de transição. De acordo com as análises de Hrncir (1994), os bancos privados na República Tcheca foram forçados a seguir uma linha mais agressiva para conquistar uma participação do mercado, praticando empréstimos menos prudentes. A falência de três bancos comerciais tchecos, em junho de 1994, foi clara indicação do problema. Os fundos de privatização do investimento que supervionam a maioria dos elefantes brancos assumiram encargos financeiros, mas a falência eventual de alguns deles não seria menos desestabilizante que o colapso de um banco. Na Rússia, não ocorreram falências. $\mathrm{O}$ não-pagamento entre empresas cresceu rapidamente. Em 1992 e 1993, o Banco Central perdoou essas somas, mas acabou testemunhando seu ressurgimento em nível nominalmente mais elevado (refletindo a hiperinflação). Conseqüentemente, todas as dívidas transformaram-se em más dívidas. 
Em resumo, o que se vê é uma incongruência estrutural entre poupanças privadas e necessidades de investimento. Uma vez que $80-85 \%$ do investimento total precisa ser poupado pelas próprias sociedades e somente o restante pode ser suprido por estrangeiros (22), é provavelmente correto considerar o gargalo financeiro como o mais grave obstáculo à modernização na Europa Central e Oriental. De fato, o auxílio externo pode, na melhor das hipóteses, ter uso limitado na liberação de uma restrição institucional. A menos que tal problema seja resolvido, quanto maior for o auxílio externo, mais dinheiro será desperdiçado.

Com esses fatores em mente, poder-se-ia esperar que os governos da região desempenhassem maior papel no financiamento do investimento do que os das economias maduras desempenhariam, o que chama a atenção para as óbvias tarefas de fornecer bens públicos e cuidar de questões externas. Mais importante, porém, são a necessidade de se criar um quadro regulador estável e transparente, a condução de políticas econômicas estáveis e competentes que possam elevar a credibilidade de agentes, instituições e regras.

Para estabilizar e promover a propensão a investir em direitos de propriedade seguros, o princípio geral de direito e a imposição judiciária dos contratos privados são de importância crucial. Nada disso pode ser considerado como dado na Europa Central e Oriental. Mesmo supondo que esses e os princípios gerais de políticas macroeconômicas confiáveis podem ser observados, é preciso dar-se conta de até que ponto eram simplistas e enganosos os primeiros debates sobre propriedade pública versus privada, proprietários reais, velocidade da mudança de propriedade ou o papel desejável do setor público versus o setor privado. A questão não está em que os idealizadores do sistema decidam a que participação da propriedade privada podem triunfantemente declarar a passagem do Rubicão do capitalismo.

A questão consiste em como os bancos e agências estatais podem enfrentar a emergência e o funcionamento de uma ordem econômica competitiva e liberal que, por necessidade, será diferente do que é o capitalismo norte-americano. Em primeiro lugar, será difícil privatizar a maioria dos bancos enquanto o problema dos ressurgentes maus débitos estiver sendo superado. Sem um elaborado sistema bancário, é difícil visualizar um elaborado mercado de ações: seria um telhado sem o próprio edifício. Em segundo lugar, embora as empresas possam ser privatizadas, se essa for uma prioridade ideológica, através, por exemplo, de esquemas de livre distribuição, tal procedimento poderá não ser razoável ou útil. Embora realmente mudem o título de propriedade, esses métodos não provêem dinheiro novo ou governança corporativa razoável. A inclusão de fundos de investimento apenas protelou, mas não solucionou tais problemas (Mládek, 1994).

No Chile, a privatização forçada dos bancos levou à sua renacionalização no início dos anos 80 . O problema, portanto, não é a mera transferência de título, como acreditam os políticos, mas a reestruturação e a viabilidade duradoura das novas empresas. 
Ao contrário das crenças reiteradas nos debates iniciais sobre a transformação, a velocidade da mudança de propriedade não é uma variável independente que possa ser calibrada à vontade. Não somente considerações de oferta, mas também as de demanda têm um papel a desempenhar. A menos que os imensos custos incorridos pela ex-República Democrática da Alemanha possam ser cobertos em outras sociedades, como também por recursos externos, não há maneira sensata de orquestrar a mudança da propriedade de acordo com uma agenda prefixada. Não foi por acaso que, quaisquer que tenham sido as ideologias de transformação, cada país da Europa Central e Oriental aplicou inúmeras formas, com os esquemas de privatização em massa desempenhando, na melhor das hipóteses, um papel complementar. O papel macroeconômico do setor público manteve-se significativo, com $40 \%$ do PIB polonês e húngaro e $60 \%$ do tcheco em 1993, com maiores participações na indústria e no sistema bancário. Em resumo, ao contrário dos modelos e planos, o setor público continua sendo um fenômeno duradouro nos países em transformação, também no setor de comércio exterior competitivo.

Isto ressalta a importância de se encontrar modelos e meios pelos quais as empresas públicas e os bancos estatais possam ser regulados, para que se comportem em conformidade com as regras de um mercado competitivo. Isso não torna supérfluo o apoio a novas entradas domésticas e estrangeiras. Seria, entretanto, ingenuidade supor que a competição externa cuidará sozinha de todo o problema. A menos de regulada e canalizada por uma estratégia coerente (sobre isto, cf. Welfens, 1994b), a emergência da propriedade privada estrangeira poderá se transformar em fonte de tensões, começando com pressões para proteção de mercado e de abusos de posições dominantes no mercado.

Voltando às empresas públicas, diversas medidas podem conjuntamente delimitar um comportamento pró-competitivo. Antes de mais nada, a insolvência deve ser sancionada. Ninguém, exceto as autoridades públicas, pode elaborar e impor uma legislação de falência. Esta, por sua vez, cuidará da saída e do rebaixamento do falho gerenciamento corporativo, igualmente nos setores público e privado. A aplicação de procedimentos de falência é um fundamento para que o saneamento do mercado faça sentido. Tanto mais que é único meio pelo qual a reorganização no micronível ocorre com base apenas nas informações descentralmente disponíveis e via coordenação horizontal de uma multitude de considerações e interesses referentes ao credor, ao produtor, ao emprego e à tecnologia. A experiência húngara no período 1986-1994 não empresta apoio aos temores exagerados de que $30-50 \%$ das produções industrial e agrícola seriam imediatamente devastados por uma medida tão "drástica". Em vez disso, ocorreu um processo de se aprender fazendo, do qual os bancos comerciais se tornaram cientes: a pior opção possível seria a insistência em fechar os seus clientes. Através de liquidações, cerca de $10 \%$ de seus direitos podem ser recuperados, ao passo que uma nova gestão tem a oportunidade de descobrir algo razoável. Mesmo que o fechamento se torne inevitável, quando ocorre em etapas, pode causar menor embaraço político. Por exemplo, a gigante Diósgyör, produtora de arma- 
mentos, foi finalmente fechada em 1994 após seis anos de agonia, com a maior parte de sua mão-de-obra já desligada e o registro de várias equipes administrativas comprovando que realmente não havia outra saída.

Similarmente aos procedimentos de falência que se aplicam às empresas privadas, públicas ou cooperativas, sejam elas domésticas ou estrangeiras, prescrições judiciosas na atividade bancária cuidariam da maioria dos problemas que alguns teóricos esperavam que ocorressem pela mudança de propriedade. Em primeiro lugar, é preciso impor os padrões contábeis europeus para superar a escrituração contábil inflacionária que exibe gordos lucros onde deveriam constar números vermelhos. Em segundo lugar, é necessário impor a obrigatoriedade de provisões para perdas e requisitos de reserva. Em terceiro lugar, uma estrita fiscalização profissional da administração bancária se faz necessária. Se, por exemplo, importantes injeções de dinheiro público se tornarem inevitáveis em conseqüência, digamos, dos riscos comerciais extraordinariamente elevados, descritos acima, uma mudança de guarda e elaboração de estratégia formalizada de sobrevivência, incluindo prazos finais e critérios de desempenho são necessárias e devem ser verificadas no devido tempo.

A julgar pelas experiências húngara, tcheca, russa e polonesa, a mão invisível per se não dará conta dessas complexas condições. Por ora, existem estratégias distintas de se abordar a questão da má dívida (para detalhes técnicos, veja Bonin, 1993). Em cada um dos casos, torna-se necessária a fiscalização governamental de regulamentações previdentes e de observância de obrigações contratuais tanto pelos bancos, quanto pelas empresas reestruturadas ou garantidas por fiança. Se as fianças tornam-se regras ou exceções e, portanto, se a pergunta for sobre qual comportamento - competitivo ou objetivando renda - vale mais a pena, a resposta continua a ter que ser dada pelo comportamento real das autoridades. A evolução das normas e mesmo a escolha entre elas é, assim, um processo espontâneo, crucialmente dependente da condução das políticas governamentais.

Como visto acima, a participação governamental no risco e a elaboração de esquemas apropriados que dividam as responsabilidades de maneira justa, continuam sendo condição vital para que o financiamento às empresas se torne viável. $\mathrm{Na}$ ausência das condições descritas está fadada a sobreviver a situação atual, na qual sólidos projetos comerciais não podem suportar a tremenda carga dos juros sobre os créditos ( $15 \%$ em termos reais na Hungria, em 1993-94) (23), enquanto aqueles que oferecem tais retornos não podem, obviamente, ser levados a sério por banqueiro competente algum.

Em resumo, o alivio do gargalo financeiro e a implantação de normas de comportamento civilizado de mercado continuam sendo as tarefas centrais das políticas específicas de transformação na Europa Central e Oriental. Isso está longe de ser a totalidade de suas macropolíticas: política econômica convencional sólida, administração monetária e políticas econômicas externas continuam sendo igualmente importantes. O domínio dessas tarefas continua sendo um trabalho por si só, enquanto os problemas aqui examinados constituem o alicerce 
do que é peculiar na estratégia de modernização na Europa Central e Oriental. A combinação deles pode ser a resposta certa ao desafio que os seus países enfrentam em sua tentativa de sair do impasse do processo de modernização.

\section{Visão geral e perspectivas}

Do que foi dito acima, segue-se que os tradicionais indicadores macroeconômicos, como o crescimento do PIB ou o índice de produção industrial, além de outros indicadores quantitativos, como a participação do setor privado, por mais importantes que possam ser, representam somente informações limitadas sobre o estado de coisas na Europa Central e Oriental. Maiores incrementos podem ou não refletir melhor desempenho. Níveis menores de desemprego normalmente refletem atrasos nas reformas institucionais e na mudança estrutural. De acordo com o padrão de desemprego, a Ucrânia e a Belorus foram as campeãs européias, com $0,5 \%$ de desemprego em meio a uma produção em colapso. A participação da propriedade privada supera $90 \%$ na agricultura polonesa, ainda que o setor seja considerado como uma criança problemática, um sinônimo de retrocesso. As estatísticas oficiais russas e tchecas indicam cerca de $50 \%$ de propriedade privada na indústria, embora esta muitas vezes signifique a propriedade de fundos de investimentos pertencentes a bancos públicos. Qualquer número ou afirmativa precisa ser interpretado com cuidado, num contexto apropriado.

Como parte do início da modernização, os principais processos e políticas de reestruturação e reajuste decolaram. Eles já apresentaram realizações substanciais, como o redirecionamento das relações comerciais do Leste para o Ocidente e a manutenção de um regime aberto de comércio exterior, com certo grau de conversibilidade da moeda em cada um dos Estados em reforma (Flemming \& Rollo, 1992), exceto na Ucrânia e na Belorus. Demonstrou-se que os últimos são ingredientes cruciais na manutenção e na implantação de normas de comportamento competitivo tanto no micro, quanto em macroníveis.

Argumentamos que a recuperação da produção e do emprego perdidos é ilusória e indesejável; conseqüentemente, alcançar os nípeis pré-crise é uma falsa unidade de medida. O estado pode fazer muito pouco para gerar crescimento de forma direta, digamos, através de programas industriais ou de administração da demanda. Enquanto isso, há diversas funções que a mão invisivel ou a iniciativa privada é incapaz de assumir na construção institucional, na elaboração de normas e na imposição de contratos. Neste último plano, estabelecer estruturas reguladoras competentes, prover bens públicos, cuidar das externalidades, procurar meios apropriados de divisão de risco no setor bancário podem constituir áreas prospectivas para o envolvimento governamental apropriado à manutenção de uma ordem econômica liberal.

Como o crescimento de longo prazo na Europa Central e Oriental é inibido em cada um de seus fatores e a mudança sistêmica exerce sua influência no longo prazo, as oportunidades de negócio da região não estão diretamente 
correlacionadas com os macrodados. Se a criação de infra-estrutura institucional continuar de maneira competente, uma considerável penetração gradual em áreas anteriormente fechadas, como a atividade bancária, a infra-estrutura ou as grandes indústrias de escala, poderá se tornar uma aplicação lucrativa para investidores estratégicos. Concessões e outras formas de garantias estatais locais podem transformar a maioria das redes de infra-estrutura física em negócios lucrativos. Desde a geração de eletricidade até a construção de rodovias e reconstrução de ferrovias, todas elas podem oferecer muito a longo prazo. Tais projetos estão em andamento na Hungria e na Polônia e estão sendo considerados em alguns outros países.

Isso explica fenômenos - que de outro modo seriam paradoxais - como a baixa correlação entre os macrodados e os influxos de investimentos diretos estrangeiros na região. Como se sabe, no final de 1994, US\$ 8,5 bilhões ou $40 \%$ do estoque regional destinaram-se à Hungria, não conhecida por seu excelente macrodesempenho. Entretanto, para que os negócios se materializem, é condição vital a disponibilidade de uma administração corporativa competente e estável, com funções claras e objetivas e sem grande influência sobre órgãos de autogestão ou sobre a burocracia. Fracassos comerciais na Boêmia (24) evidenciam nosso ponto-de-vista: um bom macrodesempenho global pode pesar menos do que o clima comercial e sócios capazes de avaliar corretamente o verdadeiro tamanho do mercado.

Em outras palavras, uma categoria holística de maturidade de mercado pode se tornar relevante quando a decisão sobre a ampliação oriental da União Européia for contemplada em 1996. Contrariamente às expectativas dos políticos de ambos os lados, será difícil definir critérios quantitativos para a avaliação de qual país da Europa Central e Oriental está apto a ser um dos membros prospectivos da União Européia por volta do ano 2000.

Que caminho tomar para atingir tal objetivo? Observadores freqüentemente buscam a opção certa. Embora esta análise tenha destacado as características comuns e as tendências gerais, diferenças em casos individuais não são menos importantes. No mínimo, devido às diferenças nas condições iniciais, as terapias também tiveram que ser diferentes. As características do legado da reforma descritas em nossa discussão aplicam-se em graus variados aos casos individuais. $\mathrm{Na}$ antiga Tchecoslováquia, nem mesmo os mercados kolkhozianos foram tolerados; portanto, a idéia de se criar capitalistas através de um jogo popular teve sua utilidade. Na Alemanha Oriental, a importação por atacado de instituições e de recursos humanos capazes de manipulá-las foi uma opção, não-aberta a outros Estados. Na Eslovênia e na Hungria, a iniciativa gerencial e a administração de carteiras por famílias não precisaram ser inventadas. Estas e outras diferenças suplantam as considerações teóricas mais gerais (Weber \& Schüller, 1993), favorecendo a competição também entre estratégias transformacionais. Conforme Hayek (1944) e a teoria da inovação, a disputa é o melhor incentivo e também o melhor método de se descobrir aquilo que somente o conhecimento específico localmente disponível e descentralizado pode oferecer. 
A tarefa dos formuladores de políticas não é estabelecer modelos sujeitos à generalização (25), mas encontrar políticas congruentes com ambientes específicos e, ao mesmo tempo, capazes de abordar a ação comum da modernização. Isso são más notícias somente para as burocracias internacionais em sua inerente busca de padronização. Para as respectivas sociedades, bem como para a pesquisa científica, só serão notícias boas as considerações sobre restrições inerentes ao planejamento da transformação como um todo (Wagener, 1992). Destacar as limitações das políticas estatais ativas tradicionalmente cultivadas, não implica atitude de não-interferência dos governos da Europa Central e Oriental. Pelo contrário: já os seus acordos de associação à União Européia e, mais ainda, a sua preparação para prospectiva filiação (26), constituem o melhor terreno experimental para internalizar nossa conclusão. Em outras palavras, a criação de uma moderna economia de mercado e o reingresso na principal corrente da modernização diz respeito, em grande medida, às barganhas para encontrar os arranjos institucionais apropriados que constróem uma ponte entre dotes nacionalmente diferentes e o ambiente internacional in concretu.

Notas

1 Para detalhes cf. Berend e Ránki (1974) e Kaser e Radice eds. (1985).

2 Em verdade, a moderna teoria econômica considera no mínimo simplista a confiabilidade nos indicadores correntes de fluxo para avaliação do desempenho econômico global. Contudo, os regimes socialistas de fato declaram esta medida como seu indicador de sucesso comparativo.

3 É interessante notar que nas décadas de 70 e 80, a economia iugoslava em geral e sua economia principal, a sérvia, em particular, tornou-se tão dependente dos mercados russos quanto qualquer membro da Comecon, tendo realizado metade do seu comércio com os soviéticos, e vendendo a maior parte de sua produção fabril nos seguros mercados orientais.

4 Para outros detalhes, consulte Ehlirch (1960); Carr e Davies (1974), Nove (1992, p. 115-225).

5 Obviamente, num estado totalitário o poder é sempre tanto um objetivo como um meio, um valor por direito próprio e, portanto, a distinção acima tem um valor apenas relativo.

6 Os casos mais extremos de conflito entre os dois foi o levante de Berlim em 1953, o polonês e húngaro de 1956, o esmagamento do movimento reformista na Tchecoslováquia em 1968 e o da Polônia em 1981. Em cada um deles, o poder monárquico e a orientação oriental foram questionados.

7 Os relatos mais detalhados deste sistema até esta data são os de Zaleski (1980) e Kornai (1992), com o último provando teoricamente por que mesmo a mais radical das reformas não conseguiu superar as restrições inerentes ao modelo socialista.

Estudos AvanÇADOS 10 (28), 1996 
8 Quando Todor Zhivkov propôs que a Bulgária se integrasse à URSS como o $16^{\circ}$ estado-membro em 1973, sua proposta foi rechaçada imediatamente, e não apenas devido à lua-de-mel com as políticas de détente.

9 Neste sentido, é instrutivo que o nome oficial contemporâneo - integração econômica socialista - tão ciosamente empregada também por alguns especialistas ocidentais no título de seus livros, foi mais ou menos o inverso preciso da realidade. Não foi particularmente socialista, foi dominada pelos russos. Não foi econômica, mas de natureza militar/imperial. Finalmente, poderia ser tudo, exceto integração, devido às suas limitações intrínsecas em ambos os lados, como resumido acima.

10 É interessante notar que, se e quando foram iniciados alguns projetos piloto/de prestígio voltados para vendas para o exterior, eles se revelaram símbolos de falência. Basta lembrar a fábrica de automóveis Lada, vendendo o carro do ano 1966 nos anos 90, ou os enormes custos de se produzir o orgulho do regime de Honecker, o chip de 1 megabyte.

11 Com ênfase diferente, este ponto é particularmente realçado na argumentação de Kornai (1992).

12 Isto é particularmente dificultado por um ambiente voltado para a reprodução ampliada de estruturas já disponíveis, já que somente estas podem tornar-se metas prioritárias do plano.

13 Kornai (1992) enfatiza somente o segundo e o terceiro dos quatro fatores interconectados que, em nossa opinião, constituem a unidade do sistema.

14 Mesmo a mais radical dentre aquelas aprovadas e não apenas contempladas sob Gorbi, a edição Aganbegiana das reformas de novembro de 1990, não incluiu a propriedade privada, mercados de capital, a liberação das importações, liberdade na fixação de preços ou a conversibilidade da moeda, apenas para mencionar uns poucos elementos de uma ordem de mercado. O problema comum com essas reformas foi a entusiástica disposição dos observadores externos de misturar seus desejos (ou os de seu partido) com sua factual consumação. Na vida real, houve predomínio das medidas administrativas de gestão da crise por parte do governo contemporâneo, mesmo em 1989-91.

15 Cf. também a argumentação mais técnica de Winiecki (1993) numa orientação semelhante.

16 Veja também a elaboração apaixonada deste ponto de vista, por van Brabant (1993, pp. 74-79 e 93-97).

17 Bons levantamentos de razões sobre as perdas de produção em interpretações alternativas são encontrados em Williamson (1993); Lányi (1994/95) e Kornai (1993).

18 Ao mesmo tempo, também se destaca o papel focal do investimento estrangeiro direto como um marca-passos no processo global da modernização, como explicado detalhadamente por Welfens (1994a).

19 Outras formas de longo prazo são entretanto disponíveis, mas dificilmente são usadas.

20 Conforme calculado em Figyelö, v. 38, $n^{\circ} 30$, levando em conta um reembolso fiscal 
bem programado e possibilidades de pagamento de dividendo, o qual constitui , obviamente, a margem relativa ao valor de reposição do papel; a isenção fiscal foi finalmente revogada em janeiro de 1995 pela nova lei fiscal.

$21 \mathrm{Na}$ realidade, somente a ex-Tchecoslováquia levou em conta este conselho, concentrando as antigas dívidas externas no Fundo de Consolidação em 1991. Na Rússia e na Ucrânia, mas em certa medida na Bulgária e Romênia, a hiperinflação e a inflação elevada tomaram conta do velho problema da dívida. Na Polônia e Bulgária, apesar da inflação moderada ter sido benéfica aos devedores por erodir o principal, o fardo dos juros foi indexado e o estoque das dívidas antigas continuou sendo um problema.

22 Esta foi a razão empírica encontrada nos NICs e nos países do sul da Europa nos anos 70 e 80.

23 As taxas reais de juros são tão elevadas basicamente por dois motivos: 1. O Índice de Preços ao Consumidor (IPC) cresce muito mais rápidamente que os preços ao produtor, pois existem elevados impostos indiretos e regularmente muito mais transferências que a coberta em receitas fiscais (Newbery, 1993). 2. Devido a uma má carteira e elevados impostos sobre lucro, os bancos mercantis adotam uma margem de cerca de $10 \%$.

24 O influxo de investimentos diretos estrangeiros foi de US\$ 1 bilhão em 1992, US\$ 0,6 bilhões em 1993 e cerca de US\$ 1 bilhão em 1994. Além disso, todos os grandes projetos, desde os da Skoda até os das companhias aéreas, encontraram sérias dificuldades.

25 Para uma argumentação mais geral sobre os limites metodológicos da generalização da experiência da Europa Central e Oriental em uma trajetória ótima de transição de “uma” economia planejada a um "mercado", cf. Csaba (1995, capítulo 7).

26 Para mais sobre estas questões e suas complexidades, veja Wang e Winters (1994), contendo estimativas alternativas do potencial comercial da região, sob várias suposições.

\section{Referências}

ADAM, J. Planning and Market in Soviet and East European Thought. Basingstoke e Londres, MacMillan; New York, St. Martin's, 1993.

ANDROPOV, Yu. V. Ucheniie Karla Marxa i zadachi sovremennosti. (Os ensinamentos de Karl Marx e as tarefas do mundo contemporâneo). Kommunist, v. 65, n ${ }^{\circ} 1,1983$.

ÅSLUND, A. Russland in Tschernomyrdins Hand. Europa Archiv, v. 48, no 13-14, 1994.

BEGG, D. e PORTES, R. Enterprise debt and economic transformation: financial restructuring in Central and Eastern Europe. In: MAYER, C. \& VIVES (eds.), Capital Markets and Financial Intermediation. Cambridge e Nova York, Cambridge University Press, p. 230-255, 1993. 
BEREND, T. I. Contribution to the history of East-Central European integration. In: VAJDA, I. \& SIMAI, M. (eds.). Foreign Trade under Central Planning. Cambridge e Nova York, Cambridge University Press, 1971 .

BEREND T. I. e RÁNKI, Gy. Economic Development in East-Central Europe in the 19th and 20th Centuries. Nova York e Londres, Columbia University Press, 1974.

BLOMSTRÜM, M.; LIPSEY, R. E. \& ZEJAN, M. Is fixed investment the key to economic growth? Londres, CERP Discussion Paper, nº 870, nov. 1993.

BONIN, J. On the way to privatizing commercial banks: Poland and Hungary take different roads. Comparative Economic Studies, v. 35, nº 3-4, 1993, p. 103-120.

BRABANT, J. van. Lessons from the wholesale transformations in the East. Comparative Economic Studies, v.. 35, $\mathrm{n}^{\circ}$ 3-4, 1993, p. 73-102.

CARR, E. H. \& DAVIES, R. W. Foundations of a Planned Economy (1926-29). Harmondsworth (Reino Unido) e Ringwood (Austrália), Penguin Books Ltd., 1974.

CHEN, K.; JEFFERSON, G.H. \& SINGH, I. Are there lessons from China's economic policies? In: HILLMAN, A. I. e MILANOVIC, B. (eds.) The Transition from Socialism in Eastern Europe. Washington, The World Bank, 1992, p. 105-129.

CSABA, L. Eastern Europe in the World Economy. Cambridge e Nova York, Cambridge U.P., 1990.

Russia beyond perestroika. Communist Economies and Economic Transformation, v. 4, $\mathrm{n}^{\mathrm{O}} 3$, 1992, p. 333-359.

. The Capitalist Revolution in Eastern Europe. Cheltenham (Reino Unido) e Brookfield (Vermont, EUA), E. Elgar Publishing Co (membro da Ashgate Publications), 1995.

DABROWSKI, M. 'The role of the government in post-communist economies. In: CSABA, L. (ed.). Privatization, Liberalization and Destruction: Recreating the Market in Central and Eastern Europe. Aldershot (Reino Unido) e Brookfield (EUA), Dartmouth Publishing Co., 1994, p. 21-34.

EHRLICH, A. Soviet Industrialization Debates (1928-1940). Cambridge (Mass.), Harvard University Press, 1960.

Flemming, J. \& ROLlO, J. (eds.). Trade, Payments and Adjustment in Central and Eastern Europe. Londres, EBRD e RIIA, 1992.

HAYEK, F. A. The Road to Serfdom. Chicago, Chicago University Press, 1944.

HERR, H.; TOBER, S. \& WESPTHAL, A. Output collapse and economic recovery in Central and Eastern Europe. In: HERR, H.; TOBER, S. \& WESTPHAL, A. (eds.). Macroeconomic Problems of Transformation. Cheltenham and Brookfield, E. Elgar, 1944, p. 1-44.

HILLAN, A. e SCHYTZER, A. Creating the reform-resistant dependent economy: socialist comparative advantage, enterprise incentives and the CMEA. In: HILLMAN, A. \& MILANOVIC, B. (eds.) The Transition... op.cit., 1992, p. 243-262. 
HRNCIR, M. Financial intermediation in ex-Czechoslovakia: an assessment. In: CSABA, L. (ed.). Privatization... op.cit., 1994, p. 167-188.

KASER, M. \& RADICE (eds.) The Oxford Economic History of Europe (1814-1980), v. I-V, Oxford, Oxford University Press, 1985.

KOLODKO, G. W. Stabilization, recession and growth in a postsocialist economy. Most, v. $4, \mathrm{n}^{\mathrm{O}} 1,1992$, p. 3-38.

KORNAI, J. The Socialist System. The Political Economy of Communism. Princeton e Oxford, Clarendon Press, 1992.

. 'Transformational recession. Economie Appliquée, v. 38, nº 3-4, 1993.

LÁNYI, K. Gazdasági visszaesés Magyarországon és más országokban, I-II. (Recessão econômica na Hungria e no exterior, partes I-II). Társadalmi Szemle, v. 49, $\mathrm{n}^{\mathrm{O}} 12$, 1994 e v. $50, n^{\circ} 1,1995$.

MISES, L. Economic calculations in the socialist commonwealth (1920). In: Hayek, F.A. ed, Collectivist Economic Planning. Londres, Routledge and Kegan Paul, 1935, p. $87-130$.

MLÁDEK, J. A csehországi privatizáció (Privatização na Boêmia). Külgazdaság, v. $38, \mathrm{n}^{\circ} 4$, p. 28-38, 1994.

NEWBERY, D. Tax and expenditure policies in Hungary. In: Economics of Transition, v. $1 . \mathrm{n}^{\circ} 2,1993$.

NOVE, A. An Economic History of the USSR (1917-1991), ( $6^{\circ} \mathrm{ed}$. final). Londres, Penguin Books, 1992.

OKUN, A. The Big Trade-Off: Efficiency versus Equality. Washington, The Brookings Institution, 1975.

PERKINS, D. Completing China's move to the market. The Journal of Economic Perspectives, v. 8, $\mathrm{n}^{\circ} 2$, p. 23-46, 1994.

ROSATI, D. Changing trade patterns and industrial policy: the case of Poland. In: GÁCS, J. \& WINCKLER, G.( eds.). International Trade and Restructuring in Eastern Europe. Heidelberg, Physica Verlag, 1994, p. 155-182.

SOLOW, R. A contribution to the theory of economic growth. The Quarterly Journal of Economics, v. 70, $\mathrm{n}^{\circ}$ 1, p. 65-94, 1956.

VOSZKA, É. The revival of redistribution. Acta Oeconomica, v. 45, nº 1-2, 1994.

WAGENER, H.-J. Wieweit ist Systemtransformation planbar? In: ALBECK, H. (ed.). Wirtschaftsordnung und Geldverfassung. Göttingen, Vanderhoek and Ruprecht, 1992, p. 99-115.

WANG, Zh.-K. \& WINTERS, .A. Eastern Europe's International Trade. Manchester, Manchester University Press, 1994.

Estudos AvanÇAdOS 10 (28), 1996 
WEBER, M. Die protestantische Ethik und der Geist des Kapitalismus. Gesammelte Aufsütze zur Religionssoziologie. Tübingen: J.C.B. Mohr (Paul Siebeck), v. I. p. 17206, 1972.

WEBER, R. \& SCHÜLLER, A. Von der Transformation zur Integration: Eine ordnungs-, handels-, und währungspolitische Aufgabenstellung. In: GRÖNER, H. \& SCHÜLLER, A. (eds.). Die europäische Integration als ordnungspolitische Aufgabe. Stuttgart etc., G. Fischer Verlag, 1993, p. 445-492.

WELFENS, P. Foreign direct investment and privatization, In: SCHIPKE, A. e TAYLOR, A. M. (eds.). The Economics of Transformation. Springer Verlag, Berlim etc., 1994a, p. 129-170.

Privatization and foreign direct investment in the East European transformation: theory, options, strategies. In: CSABA, L. (ed.). Privatization ... op. cit., p. 35-70.

WILLIAMSON, J. Why did output fall in Eastern Europe? In: SOMOGYI, L. (ed.). The Political Economy of the Transition Process in Eastern Europe. Cheltenham and Brookfield, E. Elgar, 1993, p. 25-39.

WINIECKI, J. The inevitability of fall of output in the early stage of transition. Soviet Studies, v. 43, $\mathrm{n}^{\mathrm{O}} 4,1991$.

. Knowledge of Soviet type economies and heterodox stabilization-based outcomes. Weltwirtschaftliches Archiv, v. 129, n 3, 1993.

ZALESKI, E. Stalinist Planning for Economic Growth (1993-19512). Basingstoke e Chapel Hill, MacMillan e University of North Carolina Press, 1980.

László Csaba é economista, professor de Economia Internacional do College of Foreing Trade, de Budapest. É membro do Comitê sobre Economia da Academia Húngara de Ciências e consultor de Kopint-Datorg, de cuja série Textos para discussão, foi autorizada a tradução do presente artigo.

Tradução de Vera de Paula Assis. Revisão de Lenina Pomeranz. O original em inglês Transition and/or Modernisation in Eastern Europe - encontra-se à disposição do leitor no IEA-USP para eventual consulta. 
Tabela 1

Crescimento econômico' no Leste e no Ocidente 1950-1988

(em percentagem)

\begin{tabular}{lrrrr}
\hline & $1950-1959$ & $1960-1969$ & $1970-1979$ & $1980-1988$ \\
\hline Paises ocidentais ${ }^{2}$ & & & & \\
Conjuntamente & 3,3 & 4,1 & 2,9 & 1,6 \\
Coeficiente de variaçãoo & 48,2 & 41,6 & 34,8 & 39,8 \\
Alemanha, RF & 6,8 & 3,6 & 2,8 & 2,0 \\
França & 3,7 & 4,7 & 3,2 & 1,1 \\
Itália & 5,3 & 4,5 & 3,6 & 1,6 \\
Japão & 7,1 & 9,4 & 4,0 & 3,4 \\
Reino Unido & 2,2 & 2,4 & 2,4 & 2,4 \\
EUA & 1,4 & 2,5 & 1,9 & 2,2 \\
& & & & \\
Paises do Comecon & & & & 1,1 \\
Conjuntamente & 4,6 & 3,7 & 2,7 & 22,3 \\
Coeficiente de variação & 33,1 & 25,6 & 29,9 & 1,2 \\
Bulgária & 6,0 & 5,2 & 2,3 & 1,9 \\
Alemanha Oriental & 7,2 & 3,2 & 3,1 & $-0,2$ \\
Polônia & 2,7 & 3,2 & 2,6 & 0,8 \\
Romênia & 4,8 & 4,2 & 4,4 & 1,2 \\
Tchecoslováquia & 3,8 & 2,4 & 2,0 & 2,0 \\
União Soviética & 4,2 & 4,2 & 2,3 & 1,1 \\
Hungria & 3,8 & 3,2 & 2,3 & \\
& & & & \\
\hline
\end{tabular}

'Crescimento médio do PIB per capita.

${ }^{2}$ Países da OECD (sigla inglesa de Organização para a Cooperação e Desenvolvimento Econômico).

Fonte: HEITGER, B. "Wirtschaftliches Wachstum in Ost und West seit 1950",Die Weltwirtschaft, no 1, p. 175, 1990. 
Tabela 2

Investimentos 1 nos países ocidentais e nos países do Comecon em 1950-1988 (em percentagem)

\begin{tabular}{lcccc}
\hline & $1950-1959$ & $1960-1969$ & $1970-1979$ & $1980-1988$ \\
\hline Países ocidentais ${ }^{2}$ & & & & \\
Conjuntamente & & & & \\
Coeficiente de variação & 22,6 & 26,8 & 27,2 & 23,9 \\
Alemanha, RF & 25,5 & 18,7 & 18,8 & 21,3 \\
França & 28,9 & 31,4 & 27,9 & 24,5 \\
Itália & 20,2 & 26,0 & 27,6 & 24,3 \\
Japão & 23,5 & 27,3 & 24,5 & 21,3 \\
Reino Unido & 20,0 & 32,4 & 39,2 & 36,8 \\
EUA & 14,5 & 19,7 & 19,1 & 16,0 \\
& 20,8 & 21,0 & 21,4 & 21,9 \\
Países do CMEA & & & & \\
Conjuntamente & & & & \\
Coeficiente de variação & 27,6 & 32,9 & 34,2 & 29,9 \\
Bulgária & 21,9 & 23,7 & 12,5 & 17,4 \\
Alemanha Oriental & -4 & $35,4^{5}$ & $34,3^{6}$ & $25,5^{7}$ \\
Polônia & $24,6^{8}$ & $21,0^{9}$ & $29,6^{6}$ & $23,3^{7}$ \\
Romênia & $28,3^{10}$ & $37,7^{11}$ & $34,8^{6}$ & $29,4^{7}$ \\
Tchecoslováquia & -4 & -4 & $42,8^{6}$ & $39,8^{7}$ \\
União Soviética & $31,9^{10}$ & $41,3^{11}$ & $33,5^{6}$ & $30,3^{7}$ \\
Hungria & 19,0 & 25,8 & 30,5 & $29,8^{12}$ \\
& 34,2 & $36,4^{11}$ & $34,8^{6}$ & $31,1^{7}$ \\
\hline
\end{tabular}

${ }^{1}$ Investimentos brutos médios; ${ }^{2}$ Países do OECD $;{ }^{3}$ Comecon; ${ }^{4}$ Não disponível; $;{ }^{5} 1968 ;{ }^{6} 1975-1979$;

${ }^{7} 1980-1987 ;{ }^{8} 1950-1958 ;{ }^{9} 1967 ;{ }^{10} 1960,1955 ;{ }^{11} 1960,1965,1967 ;{ }^{12} 1980-85$.

Fonte: HEITGER, B., p. 186, 1990. 


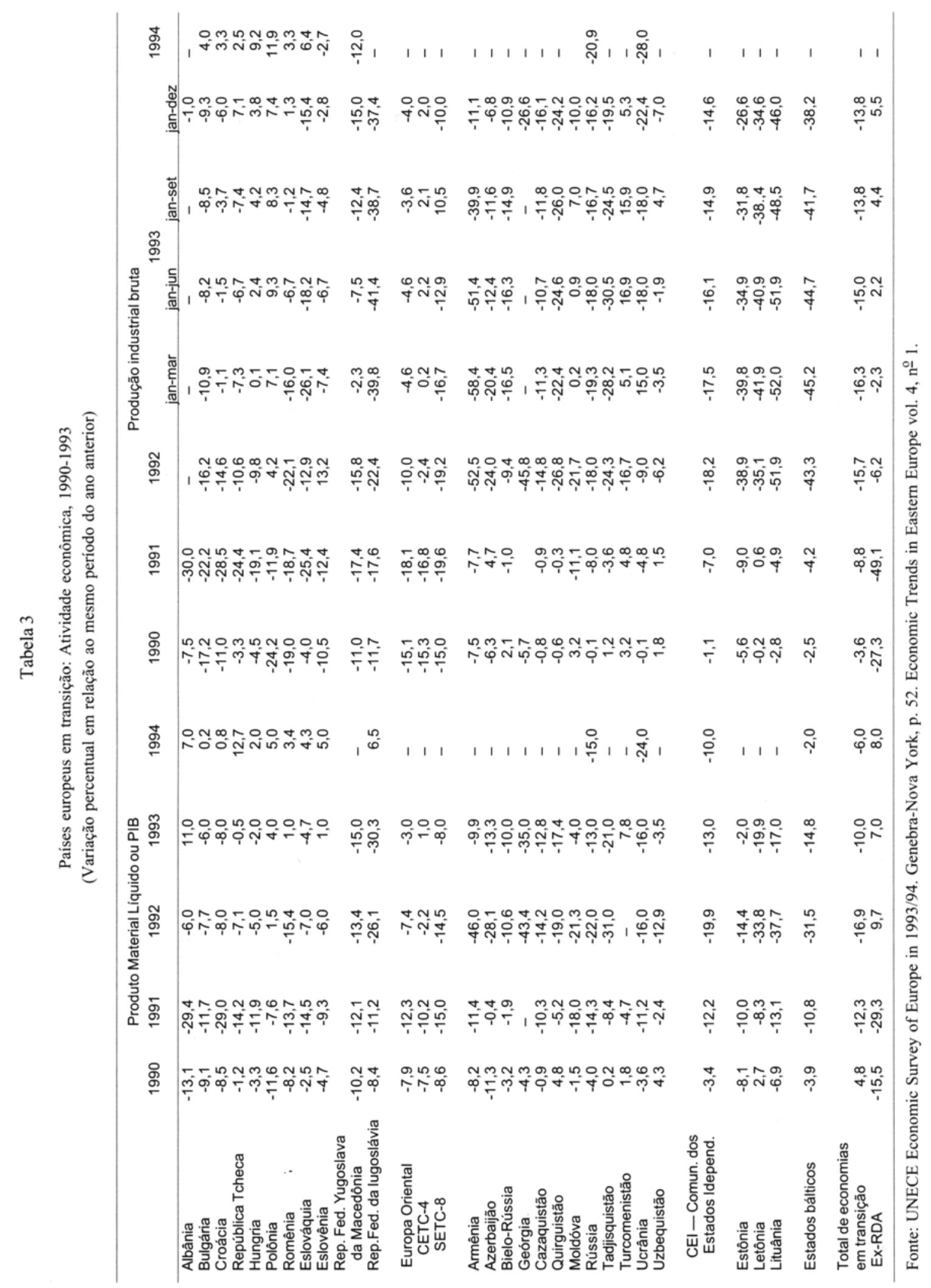

Estudos AvançAdos 10 (28), 1996 
Tabela 4

Países europeus em transição: Produção agrícola bruta 1990-1993 (Variação percental em relação ao mesmo período do ano anterior)

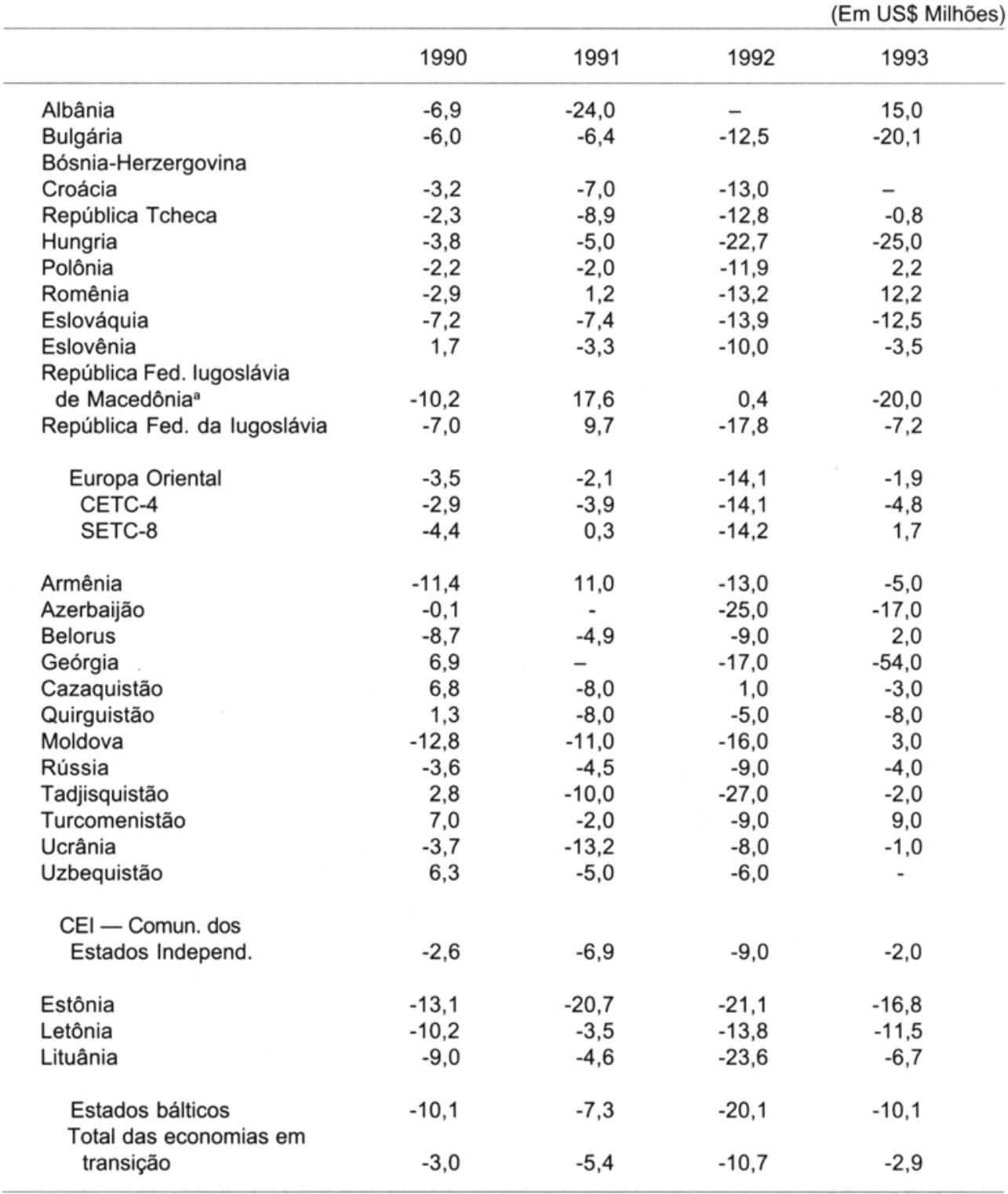

${ }^{\text {a }}$ Valor adicionado.

Fonte: UNECE Economic Survey of Europe in 1993/94. Genebra-Nova York, p. 63. 


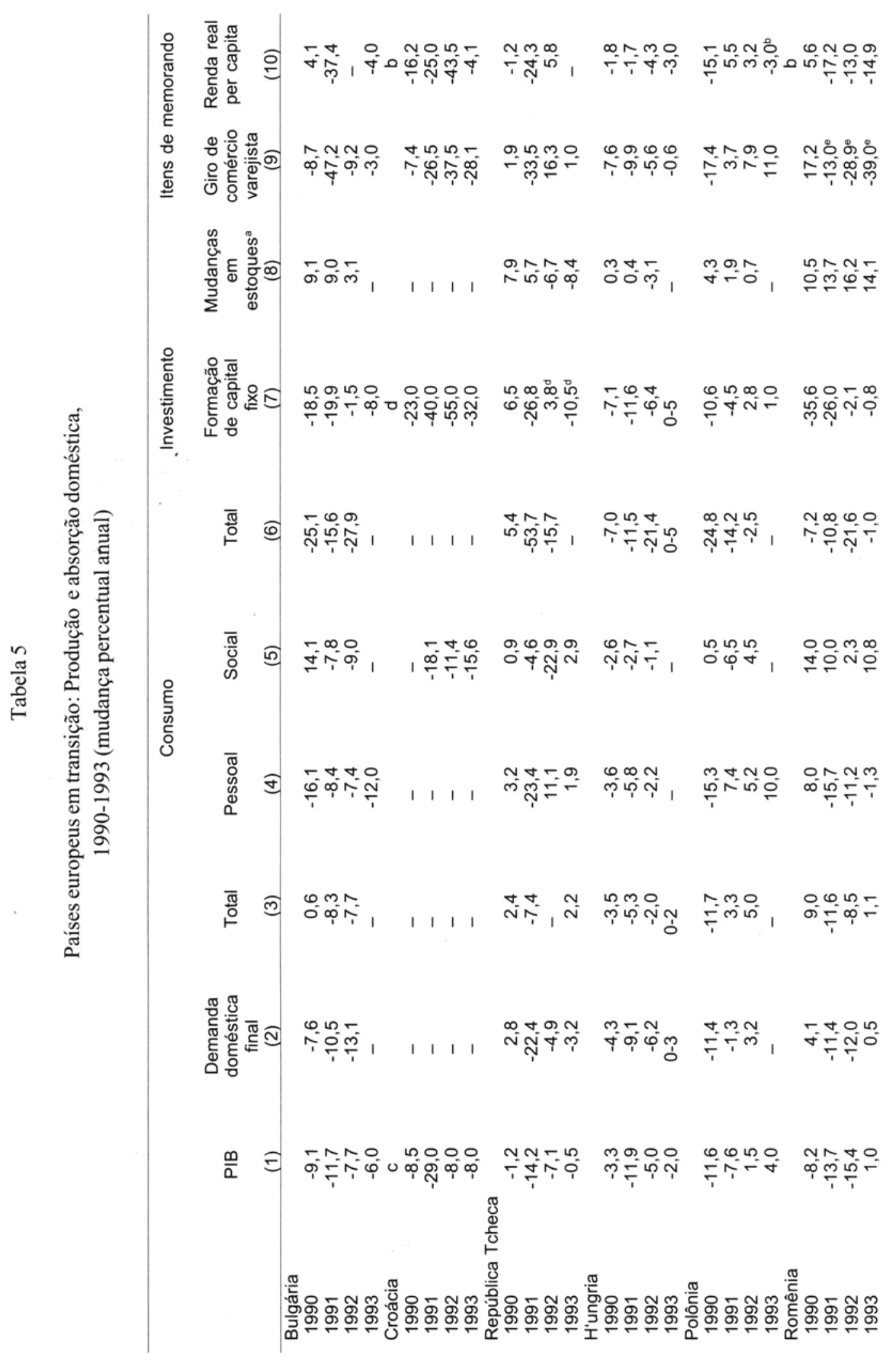

Estudos AvançAdos 10 (28), 1996 


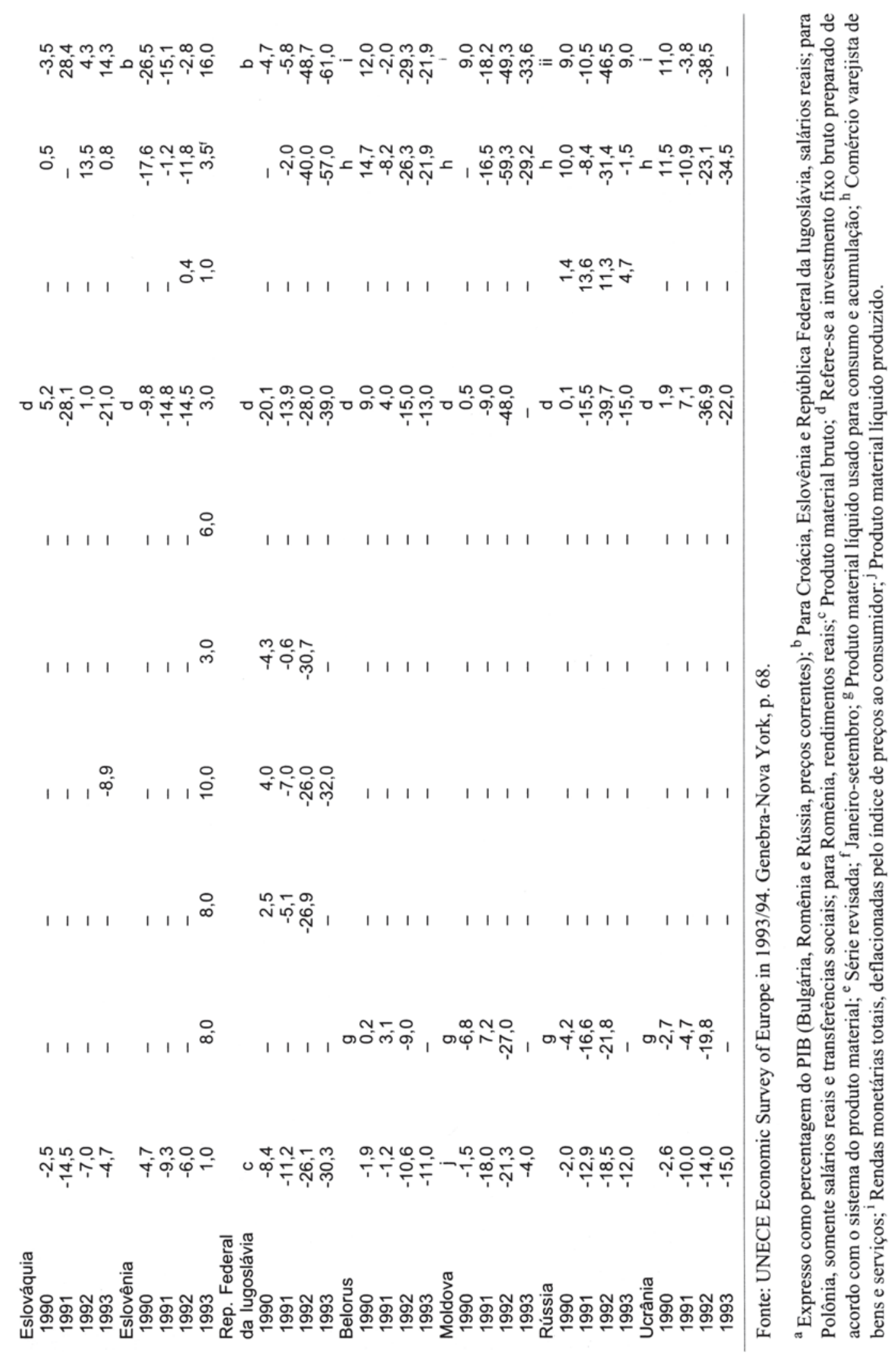


Tabela 6

Países em transição: Desemprego, 1990-1993

(Milhares e percentual da força de trabalho, final do período)

\begin{tabular}{|c|c|c|c|c|c|c|c|c|c|}
\hline & \multicolumn{4}{|c|}{ Milhares } & \multicolumn{5}{|c|}{ Percentagem da força de trabalho } \\
\hline & 1990 & 1991 & 1992 & 1993 & 1990 & 1991 & 1992 & 1993 & 1994 \\
\hline Albânia & 150,7 & 139,8 & 394,3 & 301,3 & 9,8 & 9,4 & 26,7 & 25,0 & - \\
\hline Bulgária & 72,2 & 419,1 & 576,9 & 626,1 & 1,8 & 11,5 & 15,6 & 16,2 & 13,1 \\
\hline Croácia & 195,5 & 283,3 & 261,0 & 243,1 & 8,0 & 14,1 & 17,8 & 16,9 & 18,0 \\
\hline República Tcheca & 39,4 & 221,7 & 134,8 & 185,2 & 0,7 & 4,1 & 2,6 & 3,5 & 3,4 \\
\hline Hungria & 81,4 & 406,1 & 663,0 & 632,1 & 1,7 & 7,4 & 12,3 & 12,1 & 10,4 \\
\hline Polônia & 1126,1 & 2155,6 & 2509,3 & 2889,6 & 6,1 & 11,8 & 13,6 & 15,7 & 16,2 \\
\hline Romênia & 150,0 & 337,5 & 929,0 & 1170,0 & 1,3 & 3,1 & 8,2 & 10,1 & 11,1 \\
\hline Eslováquia & 39,6 & 302,0 & 260,3 & 368,0 & 1,6 & 11,8 & 10,4 & 14,4 & 14,8 \\
\hline Eslovênia & 55,4 & 91,2 & 118,2 & 137,1 & 5,3 & 10,1 & 13,3 & 15,4 & 14,2 \\
\hline \multicolumn{10}{|l|}{ Rep.Fed. Iugoslávia } \\
\hline da Macedônia & 156,4 & 164,8 & 173,3 & 177,2 & 17,1 & 24,5 & 26,8 & 29,6 & - \\
\hline \multicolumn{10}{|l|}{ Rep. Fed. da } \\
\hline lugoslávia & 687,6 & 707,1 & 749,0 & 732,0 & 14,7 & $15, .7$ & 24,6 & 29,6 & - \\
\hline Europa Oriental & 2754,2 & 5228,2 & 6769,1 & 7460,6 & 4,8 & 9,4 & 12,5 & 13,8 & - \\
\hline CETC-4 & 1286,5 & 3085,4 & 3567,4 & 4075,0 & 4,1 & 9,7 & 11,3 & 12,9 & - \\
\hline SETC-8 & 1467,7 & 2142,8 & 3201,7 & 3385,6 & 5,6 & 8,9 & 14,2 & 15,0 & - \\
\hline Armênia & - & - & 56,3 & 102,6 & - & - & 3,5 & 6,2 & - \\
\hline Azerbaijão & - & 3,8 & 6,4 & 19,6 & - & 0,1 & 0,2 & 0,7 & - \\
\hline Belorus & - & 2,3 & 24,0 & 66,2 & - & - & 0,5 & 1,3 & - \\
\hline Geórgia & - & 1,7 & 18,9 & 39,6 & - & - & 1,0 & 2,0 & - \\
\hline Cazaquistão & - & 4,1 & 33,7 & 40,5 & - & - & 0,5 & 0,6 & - \\
\hline Quirguistão & - & 0,1 & 1,8 & 2,9 & - & - & 0,1 & 0,2 & - \\
\hline Moldova & - & 0,1 & 15,0 & 14,1 & - & - & 0,7 & 0,7 & - \\
\hline Rússia & - & 61,9 & 577,7 & 835,5 & - & 0,1 & 0,8 & 1,1 & 2,1 \\
\hline Tadjiquistão & - & - & 6,8 & 21,5 & - & - & 0,3 & 1,1 & - \\
\hline Turcomenistão & - & - & - & - & - & - & - & - & \\
\hline Ucrânia & - & 6,8 & 70,5 & 83,9 & - & - & 0,3 & 0,4 & - \\
\hline Uzbequistão & - & - & 8,8 & 13,3 & - & - & 0,1 & 0,2 & - \\
\hline \multicolumn{10}{|l|}{$\mathrm{CEI}$ - Comun. dos } \\
\hline Estados Independ & d. - & - & 819,9 & 1200,0 & - & - & 0,6 & 1,0 & - \\
\hline Estônia & 0,6 & 0,9 & 15,0 & 16,2 & - & 0,1 & 1,9 & 2,6 & - \\
\hline Letônia & - & 1,9 & 31,3 & 76,7 & - & - & 2,1 & 5,8 & - \\
\hline Lituânia & - & 4,6 & 20,7 & 30,5 & - & 0,3 & 1,0 & 1,6 & - \\
\hline Estados bálticos & - & 7,4 & 67,0 & 123,4 & - & - & 1,5 & 3,2 & - \\
\hline Total acima & - & & 7656,0 & 8784,0 & - & - & 4,1 & 4,8 & - \\
\hline
\end{tabular}

Fonte: UNECE Economic Survey of Europe in 1993/94. Genebra-Nova York, p. 86.

Economic Trends in Eastern Europe, vol. 4, no 1.

Estudos AvanÇAdOS 10 (28), 1996 
Tabela 7

Dívida externa em moeda conversível dos países em transição, 1990-1993

(Bilhões de dólares, final do periodo)

\begin{tabular}{|c|c|c|c|c|c|c|c|c|}
\hline & \multicolumn{4}{|c|}{ Divida bruta } & \multicolumn{4}{|c|}{ Divida liquida } \\
\hline & 1990 & 1991 & 1992 & 1993 & 1990 & 1991 & 1992 & 1993 \\
\hline Albânia & 0,3 & 0,5 & 0,7 & 0,8 & 0,1 & 0,4 & 0,6 & 0,7 \\
\hline Bulgária & 10,4 & 11,9 & 13,0 & 13,2 & 10,4 & 11,5 & 12,1 & 12,5 \\
\hline Croácia & 2,5 & 2,7 & 2,5 & 2,5 & 2,4 & 2,5 & 2,0 & 1,8 \\
\hline República Tcheca & 4,4 & 7,5 & 7,5 & 8,7 & 3,5 & 5,0 & 4,0 & 2,7 \\
\hline Hungria & 21,3 & 22,7 & 21,4 & 24,6 & 20,2 & 18,7 & 17,1 & 17,9 \\
\hline Polônia & 48,5 & 48,4 & 47,1 & 46,8 & 44,0 & 44,8 & 43,1 & 43,0 \\
\hline Romênia & 0,2 & 1,1 & 2,4 & 3,3 & $-0,1$ & 0,7 & 1,5 & 2,3 \\
\hline Eslováquia & 1,5 & 1,8 & 2,3 & 2,9 & 1,3 & 1,3 & 1,6 & 1,2 \\
\hline Eslovênia & 1,9 & 1,9 & 1,7 & 1,9 & 1,5 & 1,5 & 0,6 & 0,3 \\
\hline \multicolumn{9}{|c|}{ Rep. Fed. lugoslávia } \\
\hline da Macedônia & 0,5 & 0,4 & 0,7 & 0,9 & 0,5 & 0,4 & 0,7 & 0,9 \\
\hline Europa Oriental & 91,5 & 98,9 & 99,3 & 105,6 & 83,8 & 86,9 & 83,3 & 83,3 \\
\hline Moldova & - & - & & 0,2 & - & - & - & - \\
\hline Rússia & 61,1 & 65,3 & 80,8 & 85,0 & 59,5 & 64,3 & 78,8 & 79,0 \\
\hline Estônia & - & - & - & 0,1 & - & - & - & $-0,3$ \\
\hline Lituânia & - & - & - & 0,1 & - & - & $-0,1$ & $-0,2$ \\
\hline
\end{tabular}

Fonte: UNECE Economic Survey of Europe in 1993/94. Genebra-Nova York, p. 112. 